\title{
MAKALELER
}

\section{Kerbelâ Sonrasında Muhammed b. Hanefiyye'nin Yükselişi ve Siyasi Duruşu}

\author{
The Ascent and the Political Stance of Muhammad b. al-Ḥanafiyya \\ after Karbala
}

Nihal Şahin UTKU*

Öz: Hz. Ali’nin Hz. Hasan ve Hüseyin'den sonra doğan üçüncü oğlu Muhammed b. Hanefiyye'nin ismi, İslam tarih kaynaklarında özellikle Kerbelâ hadisesi ile Emevîlere karşı halifeliğini ilân eden Abdullah b. Zübeyr'in vefatı arasındaki kargaşa döneminde karş1mıza çıkmaktadır. Modern tarihçiler arasında her ne kadar onun şahsiyeti ve düşüncelerine dair ortak bir kanaat oluşmuşsa da, aynı dönemde Kûfe'de isyan başlatan ve onu mehdi olarak niteleyen Muhtâr ile ilişkisinin mahiyeti konusunda tutarlı bir izah ortaya konamamıștır. Zira bazı rivayetler, Muhammed b. Hanefiyye'nin bu harekete en azından tarafların onay gibi algıladığı bir destek vermiş olduğunu ima ederken, diğer bazı rivayetlerde ise onun Muhtâr'ın hareketini açık bir şekilde eleştirdiği, hatta ona karşı belli bir mesafe koyduğu yönünde bir intiba oluşmaktadır. İbnü’l-Hanefiyye’nin bu dönemde yaşanan gelişmeler karşısında tutarsı gibi gözükmesine yol açan bu rivayetler, tarihçilerin de onu farklı şekillerde değerlendirmelerine yol açmıştır.

Muhammed b. Hanefiyye hakkında bizim de ilgilendiğimiz bu dönemde yoğunlaşan rivayetlerle onun Kerbelâ öncesi ve Abdullah b. Zübeyr'in vefatı sonrasındaki duruşu hakkında ipuçları veren az sayıdaki malumatı birleştirdiğimizde, onun pasif direniş diye tasvir edebileceğimiz bir duruş sergilediğini söyleyebiliriz. İnanç ve düşüncelerini, Müslümanlar arasında çatışma ve fitneye yol açmayacak, ama her türlü baskıyı da göze alabilecek bir mukavemetle savunan İbnü'l-Hanefiyye’nin bu duruşu, bilahare oğlunun fikir babası olduğu Mürcie tarafından da belli ölçüde benimsenmiştir. Tavır ve ifadelerinden onun ümmetin genelinin kabul ettiği alternatif bir isim olmadıkça kendisine bir kez biat edilmiş bir halifeyle çatışmayı ve ona verilen biatı bozmayı doğru bulmadığı anlaşılmaktadır. Bu tarz bir düşünceye sahip olan birinin Muhtâr gibi isyankâr ve bilahare uç inanışlarla tanınacak olan bir kişiye ve onun hareketine nasıl destek verdiği anlaşılması güç bir durumdur. Bu makale, öncelikle İbnü’l-Hanefiyye’nin bu dönemde niçin bu kadar ön plana çıktığını ve söz konusu hareketle ilişkisini tutarsız gibi gözüken rivayetler ışığında açıklamaya çalışmaktadır. Dönemin gelişmeleri, bahse konu olan rivayetler ve rivayetlerde adı geçen râvi ve şahıslarla bir arada değerlendirildiğinde, onun tutum ve davranışlarının tutarlı bir şekilde izahı mümkün olabilmektedir.

Her şeyden önce onun isminin Kerbelâ sonrası dönemde yükselmiş olmasının altını çizmek gerekir. Bu dönem sadece Ali evladı için değil, tüm Benî Hâşim için travmatik bir dönemdir. H. 68 yılı haccında üstlendiği rol dikkate alındığında, Muhammed b. Hanefiyye’nin bu dönemde tüm Hâşimoğullarının lideri pozisyonuna geldiği ve ailenin onun

* Dr. Öğretim Üyesi, Marmara Üniversitesi İlahiyat Fakültesi, nihal.sahin@marmara.edu.tr

Orcid No: 0000-0003-2998-4026 
sancağı altında birleştiği belirgin bir şekilde göze çarpmaktadır. Gelişmeleri detaylıca okuduğumuzda, onun aynı zamanda Muhtâra da açı bir izin verdiği görülmektedir. Ancak bu izin, Muhtâra güvendiği ve onun Kûfe'de kendi namına bir kalkışma başlatmasına müsamaha gösterdiği şeklinde yorumlanmamalıdır. Daha ziyade Ehl-i Beyt'in intikamının alınmasına yönelik bir onay olarak değerlendirilmelidir. İbnü’l-Hanefiyye, muhtemelen Muhtâr'in zaten böyle bir girişim için hazırlanan Tevvâbûn hareketine katılmak veya destek vermek arzusunda olduğunu düşünüyordu. Toplumda oluşan infialin ve Muhammed b. Hanefiyye’nin en yakınlarını kaybetmiş olmasının tetiklediği bir ruh hâleti içinde verildiğini düşündügümüz bu onayın, onun genel olarak iktidar ile çatışmama prensibiyle çatışmadığını düşünüyoruz. Nitekim Muhtâr’n hırsı onu daha heterodoks ve daha da önemlisi daha politik bir yola soktuğu zaman, İbnü'l-Hanefiyye onu eleştirmiş ve Muhtâr'dan gelen destek tekliflerini açıcça geri çevirmiştir. Sadece Abdullah b. Zübeyr'in kendisine biat etmediği gerekçesiyle diğer Hâşimoğulları ile birlikte onu da hapsedip ölümle tehdit etmesi üzerine Muhtâr'dan destek almaya rıza göstermiş ve bu durumda dahi Müslümanlar arasında bir çatışma çıkmaması için elinden geleni yapmıştır. Nihayetinde de kendisini kurtarmaya gelen orduyu beraberlerinde getirdikleri paralarla birlikte dağıtmıştır.

Muhammed b. Hanefiyye her ne kadar Muhtâr ile ilişkisine belli bir mesafe koymuş olsa da, etrafında önemli bir kısmı Kûfe menşeli insanlardan oluşan bir taraftar kitlesi teşekkül etmiştir. Bunların bir kısmı, onu kurtarmak amacıyla Medine’ye gelen ordunun içinden çıkmış, diğer bir kısmı da Kerbelẩnın intikamını almak üzere adına beyatın alındığı bu şahsiyetin yanına önceden gelenlerden veya onun bu dönemde gösterdiği duruştan etkilenerek onun talebesi veya taraftarı olmayı seçenlerden oluşmuştur. Oldukça heterojen olan ve farklı geçmiş ve kültürlerden gelen bu topluluğun büyüklügünün zaman içinde değiştiğini ve önemli bir kısmının onun ölümüyle birlikte dağıldığını tahmin edebiliriz. Bununla birlikte muhtemelen daha mutedil olanlardan bir kısmının oğlu Hasan'dan ilim tedris ettiklerini ve böylece Mürcie’nin ilk teşekküllerinden birini başlattıklarını, daha radikal düşüncelere sahip olanların ise İbnü’l-Hanefiyye’nin büyük oğlu Ebû Hâşim’e intisap ettiklerini düşünebiliriz. Bilindiği gibi bu ikinci grup bilahare Abbasî ihtilalini başlatan firka ile ilişkilendirilmiştir.

Anahtar Kelimeler: İslam Tarihi, Kerbelâ, Ali evladı, Muhammed b. Hanefiyye, Muhtâr es-Sekafî, Hâşimoğulları.

Abstract: Muhammad b. al-Ḥanafiyya, the third son of 'Alī b. Abì Țālib, is a name that appears in the chaotic period between the event of Karbala and the demise of 'Abd Allāh b. al-Zubayr. While there seems to be a general agreement on the character of Muhammad b. al-Hanafiyya, there are contradicting views on his role during this period of history. Al-Mukhtār al-Thaqafi, who also emerged as a leader during this period, is known to have appropriated the name of Muhammad b. al-Hanafiyya to call the Kufans to arms, identifying Ibn al-Hanafiyya as the Mahdi; in fact, al-Mukhtār was probably the first in history to utilize this label with such a connotation. The accounts given about Muhammad b. al-Hanafiyya seem to suggest both that he supported this movement, at least in a very subtle way, and censured it to the degree of condemning it. This inconsistency of his political stance arising from different narrations has caused many historians to judge him with little sympathy and understanding.

From what can be gathered from the scant information we have on him prior to the above mentioned period, his political views and practical stance can be described as passive resistance, where a person stands his ground without actually resorting to violence, especially against fellow Muslims. He appears to have promoted that the pledge given to a caliph should not be broken without serious cause and he seems to have 
believed that opposing views are of value only as long as they are nonviolent and reasonably within the generally accepted set of beliefs. It has therefore baffled the historians as to why and how his name was used by al-Mukhtār during his rebellious movement and that it continued to be glorified among later ultra-heterodox factions. This article attempts to understand why Muhammad b. al-Hanafiyya rose to the forefront in this period, it seeks to clarify his political stance, and to determine the consistency of his relationship with the movement of al-Mukhtār, within the context of a range of accounts that could be interpreted quite differently. Through evaluation of these historical accounts and partially looking into the narrators and the names that are seen in these accounts, the article comes to the conclusion that a reasonable and consistent explanation of his behavior could be ascertained for this historical period.

It is important to note that Muhammad b. al-Hanafiyya became only highly visible as a figure with his political stance at this specific period of his life, after Karbala, at a time when not just the 'Alīds, but most of Banū Hāshim were traumatized. This leadership role of his is seen to have peaked during the Hajj of the year $68 \mathrm{AH}$, when all of Banū Hāshim gathered under his banner. From the details of the narrations and the narrators, it also seems reasonable to assume that he gave a clear consent to al-Mukhtār, not necessarily because he trusted him, but instead as an approval for al-Mukhtār go to Kufa to try to avenge the death of his family in Karbala, probably assuming he would participate with or at least work with the Tawwābūn, i.e. the penitents, who were seeking revenge for Karbala or death on the path of trying to repent. Ibn al-Hanafiyya's position towards al-Mukhtār is seen as consistent with his general political stance and this soft style of approval of his was limited with such a mission. Furthermore, Muhammad b. al-Hanafiyya denied al-Mukhtār any support when al-Mukhtār's ambitions set him forth as a more heterodox figure, and more importantly, on a more politically emphasized route. He rejected al-Mukhtār's suggestions of both material and military support, except during the final dire situation which 'Abd Allāh b. al-Zubayr put him into when he resisted to acknowledge him as the caliph of the Muslim ummah. The support sent by al-Mukhtār, probably with the help of the people of Mecca saved him, but the same material and military support was later dispersed by Ibn al-Hanafiyya.

Even with such a limited relationship, it is clear from the historical sources that a small, loose and diverse group of people did gather around Ibn al-Hanafiyya. It is reasonable to assume that a certain portion of the Kufans who came to save him from Ibn al-Zubayr's threats, stayed with him along with others who either became his students or aficionados due to the political and moral ground he displayed during this stage. It is possible that this was a small heterogeneous gathering that grew during the pilgrimage months and that probably dispersed generally after his death. However, it can be safely assumed based upon the historical sources that a certain portion of his followers stayed with either of his two famous sons: Hasan, whose students established the Murjia school (the basics of which can be found in Ibn al-Hanafiyya's stance), and Abū Hāshim, whose more radically oriented followers seem to have given rise to Hāshimiyya, the faction that seems to have been very instrumental during the Abbasid revolution.

Keywords: Islamic History, Karbala, 'Alīds, Muḥammad b. al-Ḥanafiyya, al-Mukhtār alThaqaî̀, Banū Hāshim. 


\section{Giriş}

Dördüncü halife Ali b. Ebû Tâlib'in (ö. 40/661) neslinden gelenlerin siyaset ve özellikle de aşırı uç akım ve fırkalarla olan ilişkisi, İslam tarihi ile ilgilenenlerin eskiden beri ilgisini çekmiştir. Ali evladı içinde tarihî gerçekliği ile doktrindeki yeri arasındaki farklılıkları en zor okunan şahsiyetlerden biri de Muhammed b. Hanefiyye'dir (ö. 81/700). Adına başlatılmış siyasi bir hareketle olan ilişkisi tam olarak tespit edilememiş olan bu şahsiyet, ilk dönem Şii oluşumlar içinde önemli bir yere sahip olmuş ve ölümünden sonra aşırı uç fikirlere sahip fırkaların itikadî iddialarının merkezine konmuştur. ${ }^{1}$ Ali taraftarı hareketler içinde farklı iddiaları ile başta Şia olmak üzere birçok mutedil ve aşırı akım ve doktrini etkilediğini düşündüğümüz Keysâniyye, büyük ölçüde Muhammed b. Hanefiyye’nin ulvî ve hatta ilahî kişiliği üzerine inşa edilmiştir. Oğlu Ebû Hâşime (ö. 98/716-17) nispet edilen Hâş̧imiyye firkasının da Abbâsî ihtilalinin çekirdek kadrosunu teşkil ettiği ileri sürülmüştür

Bu makale, Keysâniyye’nin ve Ebu Hâşim’in etrafında kümelenmiş olan Hâşimiyye’nin merkeze koyduğu İbnü’l-Hanefiyye’nin bu dönemde niçin ilgi çektiği, nasıl bu kadar ön plana çıarak kilit bir noktaya geldiği ve etrafında ne tür bir taraftar kitlesinin oluştuğu gibi sorulara cevap aramaktadır. İbnü’l-Hanefiyye’nin, yaşadığı dönemde ortaya çıan hareketlerle ve kişilerle ilişkilerini sorgulayan bazı çalışmalar² yapılmış olmakla birlikte, onun aşırı uç fikirlerin merkezine niçin ve nasıl taşındığı ve bilahare Hâşimiyye’yi oluşturacak kitlenin nasıl ortaya çıktığı yeterince irdelenmemiştir. Bu çalışma, söz konusu boşluğu doldurma niyetiyle o günlerin siyasi ve toplumsal şartları çerçevesinde Muhammed b. Hanefiyye’nin diğer Ali evladına nispetle nasıl ön plana çıktığını ortaya koymayı hedeflemiştir. Muhammed b. Hanefiyye’nin, adını kullanan hareketlerle ilişkileri incelenmiş ve bugüne kadar yapılan değerlendirmeleri sorgulayan, ama onun tavrını muğlaklaştıran farklı rivayetleri bir bütün olarak değerlendiren tutarlı bir açıllama getirilmeye çalışılmıştır. Bu çerçevede rivayetlerde adı geçen kişiler, râviler ve olayların geçtiği ortam bir arada değerlendirildiğinde, hem İbnü’l-Hanefiyye’nin bu yıllarda niçin ön plana çıktığını açıklayan hem de Muhtâr (ö. 67/687) ile ilişkisinin mahiyetini ortaya koyan oldukça makul ve kendi içinde tutarlı bir tablo ile karşılaşılmaktadır.

Keysaniyye’nin ve uç fikirlerinin nasıl doğduğu ve Muhtâr hareketi ile ilişkisi bu makalenin kapsamı dışındadır. Bu alanda yapılan çalışmalara ${ }^{3}$ istinaden Keysaniyye akımının

1 Belki de bu sebeplerden dolayı ilk dönem tarih yazıcıları Muhammed b. Hanefiyye hakkında müstakil eserler telif etmişlerdir. Maalesef bu eserler günümüze kadar gelmemiştir. Bk. Hüseyin Güneş, İslam Tarihinin İlk Mehdisi İbnüll-Hanefiyye, Mardin: Şırnak Üniversitesi Yayınları, 2018, s. 5-6.

2 Örneğin bk. Julius Wellhausen, İslamiyetin İlk Devrinde Dini-Siyasi Muhalefet Partileri, (trc. Fikret Işıltan), Ankara: Türk Tarih Kurumu, 1996; Sayın Dalkıran, "Muhammed b. el-Hanefiyye ve Adına Oluşan Fırkalar", Dinî Araştırmalar, Mayıs-Ağustos 2004, s. 139-158; Güneş, İbnü'l-Hanefiyye, s. 89-268; Hüseyin Güneş, "İslam Tarihinin İlk Mehdisi: Muhammed b. Hanefiyye", Uluslararası Mehdilik Sempozyumu Bildirileri, Sivas: Cumhuriyet Üniversitesi İlahiyat Fakültesi, 2018, s. 135-158.

3 Örneğin Muhtâr hareketi dahilindeki dinamiklerin Keysaniyye’nin ortaya çıkışında ne ölçüde etkili olduğu konusunda bk. Wellhausen, İslamiyetin Illk Devrinde Dini-Siyasi Muhalefet Partileri; Marshall G. S. Hodgson, "How Did The Early Shîa Become Sectarian?", Journal of the American Oriental Society, 1955, LXXV, sy. 1, s. 1-13; Vedad Kadî, "Keysâniyye’ye Özel Referansla İslam Kaynaklarında Gulât Teriminin Gelişimi” (trc. Yusuf Benli), Dinbilimleri 
doğuşu ve heterodoks fikirlere yönelmesi hususunda tüm sorumluluğu Muhtâr hareketine yıkmak makul gözükmemektedir. Zira söz konusu fırkalara atfedilen fikirlerin bir kısmının ortaya çıkışı ve gelişimi, Muhtâr hareketinin özellikle yönetici ve mevâlî kadrosunun neredeyse tamamen yok edilmesine rağmen devam etmiştir.

\section{Muhammed B. Hanefiyye'nin Hayatı ve Şahsiyeti}

Muhammed b. Hanefiyye, muhtemelen H.16/M.637 yılında Medine'de doğmuştur. ${ }^{4}$ Annesi Havle’nin aslen bugünkü Pakistan’ın güneydoğusuna tekabül eden Sind’den geldiği ve Yemâme bölgesinde yerleşik Hanîfe oğullarının cariyesi olduğu rivayet edilmektedir. Hz. Peygamber'in vefatı sonrasında sahte peygamber Müseylime (ö. 12/633) ile birlikte hareket eden Benî Hanîfe kabilesi ile yapılan savaş sonucunda Medine’ye getirilen esirler içinde yer alan Havle’nin, Hz. Ebû Bekir (ö. 13/634) tarafından Hz. Ali'ye verildiği nakledilmektedir. ${ }^{5}$

Tabii olarak bu konuda farklı rivayet ve görüşler mevcuttur. Bunlardan birinde, aslında Arap kökenli olan Havle’nin kabileler arası savaşlarda esir düştüğü, ailesinin Hz. Aliden ricası üzerine Hz. Ali’nin Havle'yi âzâd ederek onunla evlendiği nakledilmektedir. Hz. Ali’nin Hz. Ebû Bekir'in hilafetini tanımasını gerektirmeyen bu görüş özellikle Şii ulema tarafından benimsenmiştir. Benzer şekilde onun Sindli olduğu konusu da bu rivayetin sahibinin, Muhammed b. Hanefiyye ile sürekli olarak kavgalı bir ilişki süren Abdullah b. Zübeyr’in (ö. 73/692) annesi Esma bt. Ebû Bekir (ö. 73/692) olması nedeniyle tartışmalıdır. ${ }^{6}$ Hatta Havle’nin Hz. Ali’nin evine çok daha önceden girdiği ve Hz. Muhammed'in onu görerek Muhammed b. Hanefiyye’nin doğumunu daha o vakit müjdelediği bile rivayet edilmiştir. ${ }^{7}$

Bizim için vurgulanmaya değer husus, anne tarafından nesebinin, Muhammed b. Hanefiyye’nin ön plana çıktığı dönemlerde bir etkisinin olup olmadığıdır. Neticede onun Muhtâr tarafından mehdi ilan edilmesinde ve Abdullah b. Zübeyr tarafından da kendisine biat etmesi yönünde baskılara maruz birakılmasında Muhammed b. Hanefiyye'nin babasının Ali b. Ebû Tâlib olmasının bariz bir rolünün olduğu aşikârdır. Bu durumda annesinin kimliğinin, onun toplum nezdindeki itibarı açısından bir öneminin olup olmadığını sorgulamak tabii gibi durmaktadır.

Akademik Araştırma Dergisi, 2007, s. 241-276. Kezâ bu türlü uç fikirlerin İslam dünyasının çeperinde (örneğin Horasan) nasıl karşıllk bularak geliştiği hususunda bk. Güneş, İbnü’l-Hanefiyye, s. 256-257; Güneş, "İslam Tarihinin İlk Mehdisi: Muhammed b. Hanefiyye”, s. 151; Habip Demir, Horasan’da Şiilik - İran’da Şiiliğin Tarihsel Kökenleri, Ankara: OTTO, 2017, s. 63; Farhad Daftary, "Emeviler Döneminde ve Abbasilerin İlk Dönemlerinde İran, Horasan ve Mâverâünnehirdeki Mezhebi ve Milliyetçi Hareketler” (nşr. Mehmet Atalan), Kelam Araştırmaları, 2006, IV, sy. 2, s. 139-157.

4 Mustafa Öz, "Muhammed b. Hanefiyye", DİA, XXX, 537.

5 Muhammed b. Sa'd b. Menî́ ez-Zührî, Kitâbü’t-Tabakâti'l-kebîr (thk. Ali Muhammed Amr), I-XI, Kahire: Mektebetü'l-Hancî, 2001, VII, 93.

6 Bu konudaki farklı rivayet ve görüşlerin değerlendirmesi için bk. Güneş, İbnüll-Hanefiyye, s. 22-29.

7 Ebü'l-Fazl Şihâbüddîn Ahmed b. Alî b. Muhammed İbn Hacer el-Askalânî, el-İsâbe fî temyîzi’s-sahâbe, Beyrut: elMektebetü'l-Asrîyye, 2012, s. 1860. 
Hz. Hasan (ö. 49/669) ve Hz. Hüseyin'den (ö. 61/680) sonra Hz. Ali’nin üçüncü, annesi Fâtıma (ö. 11/632) olmayan çocukların da ilki olan Muhammed b. Hanefiyye, Hasan ve Hüseyin hayattayken onların gölgesinde kalmış olmalıdır. ${ }^{8}$ Bununla birlikte söz konusu durumun Hz. Alỉnin diğer tüm çocukları için de geçerli olduğu aşikârdır. Kerbelâ sonrası dönemde hayatta olduğu bilinen Hz. Ali’nin üç oğlu (Muhammed b. Hanefiyye, Ubeydullah ve Ömer) arasında anne tarafından nesebi ile ön plana çlkabilecek kimse yoktu. İbn Sa’d (ö. 230/835), Hz. Hüseyin'in geride kalan tek çocuğu Ali Zeynelâbidîn'in (ö. 94/712) annesinin de ümmüveled olduğu ve hatta $\mathrm{Hz}$. Hüseyin'in vefatından sonra onun mevlası olan Zübeyd ile evlendiği yönünde bir rivayete yer vermektedir. ${ }^{9}$ Bu sebeple özellikle Kerbelâ sonrasında sayıları oldukça azalmış olan Ali evladı içinde herhangi birinin annesinin nesebi sebebiyle ön plana çıtığı gözlemlenmemektedir. Bu durum daha sonraki dönemlerde değişmiş ve hilâfet iddiasında bulunan kimi Ali evladı, Fâtıma neslinden gelmiş olmalarını iddialarının meşruiyet gerekçeleri arasında saymışlardır. ${ }^{10}$

Muhammed b. Hanefiyye ile ilgili tartı̧ma alanlarından biri de künyesidir. Rivayetlerden anlaşıldığı kadarıyla, adının Muhammed, künyesinin de Ebü'l-Kâsım olması başlarda tartışma konusu olmuştur. Hz. Peygamber'in hem adının hem künyesinin aynı anda kullanılmaması yönündeki hadis, ${ }^{11}$ en azından Talha b. Ubeydullah (ö. 36/656) ile Hz. Ali arasında bir tartışmaya sebep olmuş gibi gözükmektedir. ${ }^{12}$ Ancak bu rivayet, İbn Sa'd'ın Tabakât'ında "Talha’nın oğlu Muhammed” başlığı altında verilen bilgilerle çelişmektedir. Buna göre Talha’nın oğlunun adı Muhammed, künyesi de Ebü'l-Kâsım’dır. Üstelik Cemel Savaşı’nda ölen Muhammed b. Talha, Muhammed b. Hanefiyye’den önce doğmuş, Hz. Peygamber’e yetiştiği için sahâbeden sayılmıştır. ${ }^{13}$

Söz konusu durumun Muhammed b. Hanefiyye’nin daha sonraları imametini ileri sürenlerce gündeme taşındığına dair elimizde herhangi bir rivayet bulunmamaktadır. Özellikle

8 Bu konudaki farklı rivayetlerin tahlili için bk. Güneş, İbnü'l-Hanefiyye, s. 98, 122-123.

9 İbn Sa'd, Tabakât, VII, 209. Tabii olarak bu konuda da çeşitli rivayetler bulunmaktadır. Onun annesinin son Sasani imparatorunun kızı olduğu özellikle Şii kaynaklarda geçmektedir. Bk. Ahmet Saim Kılavuz, "Zeynelâbidîn", DİA, LVIV, 365.

10 Örneğin ikinci Abbâsî Halifesi Mansûra karşı isyan eden Muhammed b. Abdullah en-Nefsüzzekiyye’nin iddialarından biri de kendisinin Fâtîma’nın soyundan geldiği için hilâfete daha layık olduğu şeklindeydi. Ebû Cáfer Muhammed b. Cerîr b. Yezîd Taberî, Câmi'u'l-beyân ve târîhu'l-ümem ve'l-mülûk, I-VI, Beyrut: Dâr'u'l-Kutub elİlmiyye, 1971, IV, 431.

11 Bu rivayetlerin bir kısmı Ebü'l-Kâsım künyesinin kullanılmasını tamamen yasaklamış gibi dururken, bir kısmı da hem ismin hem künyenin aynı anda kullanılmasını yasaklıyor. Bk. Muhammed b. İsmail el-Buhârî, el-Câmiu's-sahîh (nşr. Muhammed Züheyr b. Nâsır en-Nâsır), I-IV, Cidde: Darû't-Tevku’n-Necât, 1422/2001, Menâkib, 20 ve Edeb, 106; Ebü’l-Hüseyn Müslim b. el-Haccâc b. Müslim el-Kuşeyrî, Sahîh Müslim (nşr. Ebu'l-Fadl ed-Dimyâtî), Kahire: Dâr'ul-Beyânu'l-Arabî, 2006, Âdâb, 1 (2131). Muhammed b. Hanefiyye’nin kendi ismiyle ilgili hadis ve rivayet için bk. Ebû Dâvûd Süleymân b. el-Eşáas b. İshâk es-Sicistânî el-Ezdî, es-Süneni Ebû Dâvûd (nşr. İzzet Ubeyd ed-Daâs ve Adil es-Seyyid), I-V, Beyrut: Dâru İbn Hazm, 1418/1997, Edeb", 76/4967; Ebû Îsâ Muhammed b. Îsâ b. Sevre (Yezîd) et-Tirmizî, el-Câmi 'u'ṣ-șahîh (nşr. İbrahim Atveh Avd), I-V, Kahire, Muhammed Mahmud el-Halebî ve Şûrekâhu, 1395/1975, Edeb, 68/2843. 
ona aşırı bir kutsallık atfeden uç akımların onun bu hususiyetini de ön plana çıkarması beklenebilirdi. Tabii olarak ortada bu yönde herhangi bir rivayetin olmaması, böyle bir iddianın dile getirilmemiş olmadı̆̆ anlamını taşımaz.

Muhammed b. Hanefiyye’nin çocukları içinde ikisi öne çıkmıştır. Bunlardan ilki Hasan (ö. 100/718) olup, onun ilk dönem itikadî fırkalarından biri sayılan Mürcie ekolünün fikir babası olduğu söylenebilir. ${ }^{14}$ Diğer oğlu ise Ebû Hâşim olarak tanınan Abdullah'tır. Annesi ümmüveled olan Ebû Hâşim de babası gibi kendisine imamet izafe edilmiş biri olmakla birlikte aynen babası gibi taraftar kitlesiyle olan ilişkisi konusunda netlik yoktur. Bununla birlikte ona atfedilen Hâşimiyye fırkasının bilahare Abbâsî hareketinin nüvesini teşkil etmiş olduğu hususu açıktır. ${ }^{15}$ İbnü’l-Hanefiyye’nin bu iki oğlunun da soylarının devam etmediği anlaşılmaktadır. Her hâlükârda daha sonraki dönemlerde Muhammed b. Hanefiyye veya soyu ile akrabalık bağı kurarak herhangi bir iddia ile ortaya çıkmış birinin mevcudiyeti kayıtlara geçmiş değildir.

İbn Sa'd'ın Tabakât'inda yer alan rivayetlerden Muhammed b. Hanefiyye'nin Siffîn ve Cemel savaşlarına katıldı̆̆ı, hatta bayraktarlık yaptığı, ancak söz ve davranışlarından anlaşıldığı kadarıyla Müslümanlar arasında yaşanan çatışmalardan rahatsızlık duyduğu görülmektedir. Hatta bu konuda babasını eleştirdiğine ilişkin bilgiler mevcuttur. Rivayetlere göre Hz. Ali'nin Kûfelilere güvenerek Emevilerle çatışmaya girmesini sorgulamış ve Hz. Peygamber'den sonra babası da dahil olmak üzere kimsenin cennetlik olabileceğine şahitlik etmeyeceğini ifade etmiştir. Müslümanların Hâşimoğullarını ve Emevioğullarını neredeyse ilahlar olarak kabul ettiklerini ileri sürerek eleştirilerde bulunmuştur. ${ }^{16}$

Muhammed b. Hanefiyye'nin siyasi duruşu da benzer bir minvalde gelişmiştir. Siffîn sonrasında herhangi bir savaşa katıldığına dair bir bulguya rastlamadığımız İbnü'l-Hanefiyye kan dökülmesine karşı çıkarak ümmetin üzerinde ittifak ettiğine ikna olduğu halifeye biat etmiştir. Bu çerçevede ağabeyi Hz. Hasan’ın hilafetten vazgeçmesinin ardından Muaviye’ye (ö. 60/680), ardından da Yezid’e (ö. 64/683) biat vermiştir. Yezid’in ölümünün ardından ortaya çıkan kaotik ortamda da ortada tek bir halife namzedi kalana dek kimseye biat etmemiştir. ${ }^{17}$

14 Bu konuda bk. Sönmez Kutlu, “İlk Mürciî Metinler ve Kitâbü’l-İrcâ”, Ankara Üniversitesi İlahiyat Fakültesi Dergisi, 1997, sy. 37, s. 317-331.

15 Ebû Hâşim ve şiasının Abbâsîlere intikali ile ilgili tartışmalar için bk. Nihal Şahin, Abbasi Devletinin Kuruluş Safhasında Abbasoğlu-Alioğlu İlişkileri (Yüksek Lisans Tezi, 1996), Marmara Üniversitesi Sosyal Bilimler Enstitüsü, s. 36-39; Hüseyin Güneş, “Ebû Hâşim Abdullah’ın Siyasî Etkinliği”, İstem, 2011, IX, sy. 18, s. 273-283.

16 İbn Sa'd, Tabakât, VII, 94-96. Muhammed b. Hanefiyye’nin ismi, künyesi ve genel olarak yaklaşımı ile ilgili rivayetlerin çoğunun râvi zincirinin başında Ebû Ya'la Mûnzir es-Sevrî (ö. 73/692) bulunmaktadır. Bu şahıs, cerh ve ta'dil kitaplarında sikâ olarak addedilir ve İbn Sa'd'ın Tabakât'ında da Kûfeliler bahsi altında verilmiştir. Bu bilgi önemli zira az sayıda hadis rivayet eden bu kişinin rivayette bulunduğu kişilerin başında İbnü’l-Hanefiyye ve oğlu Hasan var. Bk. İbn Sa‘d, Tabakât, VIII, 427; Ebü’l-Fazl Şihâbüddîn Ahmed b. Alî b. Muhammed İbn Hacer el-Askalânî, Tehzîbü't-tehzîb, I-IV, yy.: Müessesetü’r-Risâle, 1995, IV, 155. Her ne kadar o söz konusu rivayetleri, bir ihtimal Medine’ye geldiğinde bir ilim meclisinde topluca duymuş olsa da yine de bu durum İbnü’l-Hanefiyye ailesinin etrafında sürekli olarak Kûfeli birilerinin olduğunun bir göstergesi sayılabilir. Nitekim bu makalede de değerlendirilecek olan başkaca rivayetler de bu yönde bir kanaati kuvvetlendirmektedir. 
Cemel ve Siffîn'de Müslümanların birbirleri ile savaşmasından rahatsızlık duyduğu anlaşılmaktadır. Bu savaşlarda o da babasının tarafında savaşmış ve bu durumu, o dönemde birçok şahsın da yaptığı gibi, karşı tarafın aslında hiçbir zaman Müslüman olmadığı tezi ile meşrulaştırmaya çalışmış, ancak bu iddiasından kısa bir süre içinde vazgeçmiştir. ${ }^{18} \mathrm{Bu}$ tavır değişikliğini, söz konusu savaşlardan sonra yeniden bir arada yaşama zorunluluğu, itikadî olarak aralarında ciddi farkların bulunmaması ve en nihayetinde bir dönem Müslüman saymadığı birine biat etmek durumunda kalması gibi olası sebeplere bağlamak mümkündür. Neticede daha sonra üzerinde sabit duracağı ve ümmetin icmâsını ve ortak (toplum?) menfaatini önceleyen, çatışma yerine uzlaşmayı tercih eden Mürcie’nin de ileri süreceği fikirleri benimsemiştir. ${ }^{19}$ Ona göre verilmiş olan biatı ciddi bir gerekçe olmadan bozmak büyük bir suçtu ve Cemel ve Sıffîn'de Hz. Ali tarafında savaşmanın haklılı̆ı̆ bundan kaynaklanıyordu. İbnüll-Hanefiyye, aynı sebeple Harre vakıası öncesinde Medinelileri Yezid’e olan biatlarını bozmamaları konusunda uyarmıştı. O biatını Kerbelầda yaşanan faciaya rağmen sürdürmüş ve Yezid aleyhine yapılan konuşmaları eleştirmişti. ${ }^{20}$ Ağabeyi Hüseyin’e de aynı gerekçelerle uyarılarda bulunmuş ve Yezid’e biat etmeyecek olsa bile herhangi bir kalkışma yerine Mekke’ye, orada yapamayacaksa da Yemen gibi gözlerden uzak yaşayabileceği bir bölgeye gitmesini tavsiye etmiştir. ${ }^{21}$

\section{Kerbelâ Sonrası Ali Evladının Durumu}

Muhammed b. Hanefiyye’nin ismini ön plana çıkaran gelişmeleri doğru bir şekilde değerlendirebilmek için Kerbelâ sonrası diğer Ali evladının durumunu da tetkik etmek gerekir. Bilindiği gibi, Kerbelâ vakıası İslam tarihinin en önemli kırılma noktalarından biri sayılmaktadır. Etkileri bugüne dek uzanan bu facia, hadisenin tüm taraflarının tahminlerinin ötesinde bir travma yaratmıştır. Bu çerçevede ele aldığımız tarihî dönemin, yaşanan acıların tazeliğini koruduğu bir dönem olduğunu unutmamak gerekir. Bu acı, Kûfe’de önce Tevvabûn ardından da Muhtârı’ın kalkışmasına gerekçe oluştururken, Abdullah b. Zübeyr’i de hilafet iddiasına taşımıştır. Diğer yandan, bu acı olay Tevvabûn hareketi hariç söz konusu gelişmelerin sebebinden ziyade mazereti olmuş gibi durmaktadır. Her hâlükârda, Kerbelânın o dönemdeki etkileri ile sonradan İslam toplumunun zihin dünyasındaki karşıllı̆̆ arasında ciddi farklılıkların olduğu anlaşılmaktadır ve bunun tabii olarak görülmesi gerekmektedir.

Konumuz açısından Kerbelâ sonrası dönemde Ali evladından ciddi sayıda şahsiyetin ölmesi toplumda travmatik bir boşluk oluşturmuş, bu da bir miktar hırs sahibi her potansiyel adayın harekete geçmesine müsait bir zemin teşkil etmiştir. Nitekim Abdullah b. Zübeyr’in

18 Güneş, İbnü'l-Hanefiyye, s. 232.

19 Onun siyasi duruşunu göstermesi açısından bk. İbn Sa‘d, Tabakât, VII, 97-98.

20 Ünal Kılıç, "Harre Vakıasının Sebepleri Hakkında Bazı Mülahazalar", Cumhuriyet Üniversitesi İlahiyat Fakültesi Dergisi, 2000, sy. 4, s. 319-320.

21 Ebü'l-Hasen Ahmed b. Yahyâ b. Câbir b. Dâvûd Belâzûrî, Kitabu Cümel min ensâbi'l-eşrâf, I-XII, Beyrut: Dâru’l-Fikr, 1996, V, 317-318. 
artık rahat bir şekilde kendini ortaya atmasını da ${ }^{22}$ Muhtâr gibi normal şartlarda insanların itibar etmeyeceği birinin kalkışmasını da Kerbelânın yarattığı bu travmatik boşluğa atfedebiliriz.

Öte yandan Kerbelâ her şeyden önce Ali evladına indirilmiş bir darbe olmuştur. İbn Sa'd ve Taberî (ö. 310/923) bu olay sırasında Ehlibeyt'ten hayatını kaybeden 20 civarında isim sayar. Ama savaş sonrasında Ehlibeyt ve destekçilerinin kesilmiş başlarının sayısını yetmişin üzerinde verirler. Neticede bu vakıa sırasında Hz. Hüseyin'in yanı sıra Hz. Ali’nin Kerbelầya katılmamış olan 3 oğlu dışında tüm erkek çocukları, Hz. Hüseyin'in o gün hasta olan Ali Zeynelâbidîn dışındaki tüm erkek çocukları, Hz. Hasan’ın ise yaşları küçük olduğu için yaşamalarına izin verilen Hasan ile Amr ve o gün orada olmadığı anlaşılan Zeyd dışındaki tüm erkek çocukları öldürülmüştür. ${ }^{23}$

Muhammed b. Hanefiyye’nin Hz. Hüseyin ile yola çıkmadığı, hatta onu böyle bir şeye teşebbüs etmemesi konusunda uyardığg bilinmektedir. Taberî̀deki rivayete göre Hz. Hüseyin Yezid'e biat etmemek için Medine'den Mekke’ye geçeceği zaman kardeşi ona mümkün olduğu kadar merkezlerden uzak durmasını tavsiye etmiş ve insanlar ona toplu halde biat etmedikçe onlara güvenmemesi gerektiğini vurgulamış, insanların bir kısmının ona tabi olması durumunda ise kan döküleceği uyarısında bulunmuştur. Kalabildiği ölçüde Mekke'de kalmasını, sonra da çöllerde ve dağlarda saklanıp gidişatı takip etmesini öğütlemiştir. ${ }^{24}$ İbn Sad'a göre Hz. Hüseyin Mekke'den yola çıkacağı zaman Medine’deki akrabalarına da haber göndermiş, bu sayede Medine’den de ona katılanlar olmuştur. Muhammed b. Hanefiyye de Hz. Hüseyin'in fikrini değiştirmek amacıyla peşlerinden gitmiş, ancak onu ikna edememiştir. İbnü'l-Hanefiyye’nin çocuklarını Hz. Hüseyin'e katılmaktan alıkoyması, Hz. Hüseyin'i gücendirmiş ve “Benim başıma geleceklerden çocuklarını mı esirgiyorsun?” şeklindeki sualine sebep olmuştur. İbnü'l-Hanefiyye ise ağabeyine "Benim için senin başına gelecekler çocuklarımın başına geleceklerden daha önemli. Ama senin başına gelenler, neden seninle birlikte onların da başına gelsin ki?" şeklinde mukabele etmiştir. ${ }^{25}$

Muhammed b. Hanefiyye’nin Hz. Hüseyin'e katılmaktan uzak durmasını, sonraki Şii ulema farklı şekillerde anlamlandırmaya çalışmıştır. Kimi onun Hz. Hüseyin ile gidemeyişini o günlerde hasta oluşu ile izah etmiş, kimi de esasında Hz. Hüseyin'in kendi akıbetini bildiğini, o yüzden akrabalarını yanında gitmeye zorlamadığını, dolayısıyla İbnü’l-Hanefiyye’nin imam Hüseyin’e tabi olmadığ 1 için günah işlemediğini ileri sürmüştür. ${ }^{26}$

22 Hz. Hüseyin’i gitmeme konusunda ikna edemeyen İbn Abbâs’ın Abdullah b. Zübeyr'e söyledikleri bu hususu teyit etmektedir. İbn Abbâs, Hz. Hüseyin’e Hicaz’dan ayrılmasının Abdullah b. Zübeyr’i mutlu edeceğini, zira Hz. Hüseyin orada bulunduğu sürece kimsenin ona itibar etmediğini ifade etmiş, aynı sitemi İbn Zübeyr’in yüzüne de yapmıştı. Bk. Taberî, Târîh, III, 295.

24 Taberî, Târîh, III, 271.

İbn Sa‘d, Tabakât, VI, 428-429. Hz. Hüseyin’i uyaranlar arasında, yakın akrabaları İbn Abbâs ve Abdullah b. Ca’fer de yer almaktadır. Bk İbn Sad, Tabakât, VI, 426-428.

26 "Muhammad b. al-Ḥanafiyya”, Wikishia, http://en.wikishia.net/view/Muhammad_b._al-Hanafiyya, (erişim tarihi: 10 Aralık 2017) 
Netice itibariyle Ali evladından Muhammed b. Hanefiyye ve çocukları Hz. Hüseyin ile yola çımmamıştır. Bu sebeple Kerbelâ sonrasında hayatta kalan en büyük Ali evladı olarak Muhammed b. Hanefiyye’nin belli bir saygı ve ilgiye mazhar olması makul gözükmektedir. Bununla birlikte Hz. Ali’nin oğullarından geride sadece Muhammed b. Hanefiyye kalmamıştır. Hayatta kalanlardan biri de hakkında yeterince bilginin bulunmadığı ve Şii kaynakların da pek bahsetmediği Ubeydullah’tır. İbn Sad ve Taberîde geçen rivayetlere göre Ubeydullah (ö. 67/687), Muhtâr’’n üzerine yürüyen Mus’ab b. Zübeyr’in (ö. 72/691) ordusunda savaştığı sırada öldürülmüştür. Hatta İbn Sa'd’ın Tabakât'ında geçen rivayetler doğruysa, kısa bir süre Muhtâr'la muhatap olmuş ve onun tehditleri üzerine Basra'ya Mus'ab’ın yanına kaçmıştır. Burada ona biat etmek isteyen bir grup insan çıkmış, o bundan hoşnut olmasa da Mus̉ab olayı öğrenene kadar onlara karşı çıkmamıştır. ${ }^{27}$

Hz. Ali’nin Ümmü Habib’ten olan oğlu Ömer’in de Hz. Hüseyin ile sefere çıkmadığı ve uzun bir ömür sürdükten sonra Yenbu'da öldüğü bilinmektedir. ${ }^{28}$ Onun Hz. Ali’nin vakıfları sebebiyle kardeşleri Hasan ve Hüseyin'le, bilahare de çocuklarıyla çekiştiğine ve konunun Abdülmelik b. Mervan’a (ö. 86/705) kadar ulaştığına dair rivayetler vardır. Ömer’in önce Abdullah b. Zübeyr’e, onun öldürülmesi üzerine de Abdülmelik b. Mervan’a biat ettiği görülmektedir. ${ }^{29}$ Onun bu anlamda muhalif hareketlerin ilgisini çekebilecek bir konumdan uzak olduğu anlaşılmaktadır.

Hz. Hüseyin ile yola çıkmayanlar arasında Ali evladından olmasa da Hâşimiler için potansiyel olarak ön plana çıkabilecek iki isimden daha söz edebiliriz: Abdullah b. Ca’fer b. Ebû Tâlib (ö. 80/699-700) ve Abdullah b. Abbâs (ö. 68/687-88). Hz. Hüseyin'in amcaoğlu olan Abdullah b. Ca’fer, Müslümanların ilk hicret mekânı olan Habeşistan'da doğmuş olduğu için bilinen bir şahsiyetti. Babası Mûte şehitlerinden olan Abdullahỉn annesi bilahare Hz. Ebû Bekir ile evlenmişti. Eşlerinden birinin Hz. Ali ve Fatıma’nın kızı Zeynep olması sayesinde oldukça muteber bir akraba çevresi bulunmaktaydı. Müslümanlar arasında cömertliği ile maruf olan Abdullah, Kerbelâ olayı sırasında 67 yaşlarındaydı. Sefere katılmamış ve Hz. Hüseyin'i de çıkmaması konusunda uyarmıştır. Bununla birlikte oğulları Avn ve Muhammed Kerbelâya gitmiş ve Hüseyin ile birlikte öldürülenler arasında yer almıştır. Hatta oğullarından Kasım’ın da Kerbelâya katıldığı ve hayatta kaldığı yönünde bir rivayet aktarılsa da ${ }^{30}$ kaynaklarda bu hususu teyit eden başkaca bir rivayete rastlayamadık.

Diğer yandan yıllar sonra Abdullah b. Ca’fer'in oğlu Muaviye’nin (ö. 129/746-47) çocuklarından Abdullah’ın hilafet iddiasında bulunması ve aralarında Hâş̧imiyye taraftarlarının ve hatta bilahare Abbâsîlerin ikinci halifesi olacak olan Mansur'un (ö. 158/775) da katıldığı bir isyan başlatmış olması ilginçtir. Bu hareket Kûfe'de başlamış ve hem Zeydî hem de daha uç

27 İbn Sad, Tabakât, VII, 118; Taberî, Târîh, III, 489.

28 Taberî, Târîh, III, 162.

29 Güneș, İbnül-Hanefiyye, s. 140-141.

30 İbn Sa'd, Tabakât, VI, 443. 
unsurlar tarafından desteklenmiştir. ${ }^{31}$ Söz konusu durum, Kureyş’in Hâşimî kolundan herkesin hilafet için aslında potansiyel bir aday olduğunu göstermektedir.

Yaşı ilerlemiş olmasına rağmen sosyal hayatın içinde bulunduğu anlaşılan Abdullah’ın Muaviye ile iyi ilişkiler içinde olduğu bilinmektedir. Bir rivayete göre, Muaviye'nin onun yanında Hz. Hüseyin'e hakaret etmesi nedeniyle Abdullah Şam'dan ayrılmışsa da, Muaviye’nin yaptığından pişmanlık duyarak ona mal ve mülk hediye etmesi, ölüm döşeğindeyken de oğlu Yezid’e Medine'de Abdullah b. Ca’fer'e güvenebileceğini söylemesi kayda değerdir. ${ }^{32}$ Keza Abdullah'ın Medine'de gerçekleşen Harre olayını engellemek için gayret sarf ettiği tahmin edilmektedir. ${ }^{33}$ Kızının halife Abdülmelik’in meşhur valisi Haccac b. Yusuf (ö. 95/714) ile evlendiği de rivayetler arasındadır. ${ }^{34} \mathrm{Bu}$ rivayetler, onun dönemin yöneticileri ile iyi ilişkiler içinde olduğunu ve herhangi bir muhalefet hareketine destek çıkmadığını göstermektedir.

Bu dönemde Hâşimoğulları içinde dikkat çeken bir başka isim Abdullah b. Abbâs'tır. Yaşadığı dönemde gelişen olayların önemli bir kısmında ismiyle karşılaştı̆̆ımız İbn Abbâs’n, Abbâsî propagandası olduğu anlaşılan rivayetlerde şahsı ve çocukları için siyasi emeller taşıdığı izlenimi verilmektedir. ${ }^{35} \mathrm{Bu}$ iddialara karşılık onun en baştan itibaren Ali evladının yanında durduğu ve Abdullah b. Zübeyr'in hakimiyeti altındaki Mekke’de Muhammed b. Hanefiyye ile aynı kaderi paylaştığı görülmektedir. Kaynaklardaki rivayetlerden İbn Zübeyr’e biat etmeyen Hâşimoğulları içinde özellikle bu iki isim ön plana çıkmaktadır. İbnü’l-Hanefiyye ile İbn Abbas arasındaki yakın ilişki, bilahare Ebû Hâşim’in Hâşimiyye fırkasını İbn Abbâs'ın torunu Muhammed b. Ali'ye emanet ettiği ve imamet hakkının Abbâsîlere geçtiği iddialarına zemin hazırlamış olabilir. Neticede Abdullah b. Abbâs’ın dönemin siyasi ve sosyal gelişmelerinde aktif olduğu, bununla birlikte kendi nam ve hesabına bir beklenti içinde olmadığı, kendisinin ve babasının Hâşimoğulları içinde tabii lider konumunda gördüğü Hz. Ali ve evladına destek verdikleri anlaşılmaktadır. ${ }^{36}$

Kerbelâ sonrasında yaşanan öfke ve muhalefet ortamının Ehlibeyt içinden ön plana çıkarabileceği adayları değerlendirirken ilk akla gelen isimleri en sona bırakmış olduk. Kerbelâ vakıasından sağ çıkmış olan Hasan ve Hüseyin evladını, tabii olarak hem hürmet hem de intikam duygularının etrafında toplanacağı en güçlü adaylar olarak görmek gerekir. İlginç bir

31 Detaylar için bk. Şahin, Abbasoğlu-Alioğlu İlişkileri, s. 102-104.

32 İbn Sa'd, Tabakât, VI, 467-468.

33 Harre vakıasının sonuçları Yezid’e ulaştığında Abdullah b. Ca’fer'in onun yanında olduğu ifade edilir. Yezid, Medine'yi talan eden komutan Müslim b. Ukbe’nin mektubunu onunla paylaşır ve istişare eder. Bk. Ebû Muhammed Abdullah b. Müslim İbn Kuteybe, el-İmâme ves-siyâse (Hilafet ve Siyaset) (trc. Cemalettin Saylık), Ankara: Ankara Okulu, 2017, s. 293. Mes'ûdî (ö. 345/956), Abdullah b. Ca’fer’in Harre olayında öldürüldüğünü yazmısssa da bu diğer rivayetlerle uygunluk arz etmemektedir. Bk. Ebu Hasan Ali b. Hüseyin Mes'ûdî, Mürûcu'z-zeheb ve meâdini'lcevher, I-IV, Beyrut: Daru’l-Fikr, 1997, III, 80. Abdullah b. Ca’fer'in Harre sırasındaki rolü hakkında bk. Kılıç, "Harre Vakıasının Sebepleri Hakkında Bazı Mülahazalar”, s. 320.

Güneş, İbnü'l-Hanefiyye, s. 186. Abbas ve veledihi (thk. Abdulaziz Dûrî ), Beyrut: Dâru’t-Talîah li Matbûa ve’n-Neşr, 1971, s. 43, 85-88. 
şekilde bu iki aile içinden sonraki dönemlerde isyan başlatmış, muhalif hareketlere katılmış ya da öncülük etmiş veya kendi namlarına imamet ve/veya hilafet iddiasında bulunmuş şahsiyetler çıkmış olsa da Kerbelâyı yaşayıp hayatta kalan Ehlibeyt mensupları kendilerini iyice dışa kapatmış ve herhangi bir iddia ile yakından uzaktan anılmak istememişlerdir. Bu durum, Kerbelâ faciasında oldukça genç yaşta olan bu önemli şahsiyetlerin yaşadıkları travma ile açıklanabilir. Kerbelâ sonrası hayatta kalabilenler kadın erkek, yaşlı çocuk demeden zorlu şartlar altında, kimi zaman aşağılanmaya ve hakarete maruz bırakılarak Şam’a kadar götürülmüşler, burada da bireysel ve toplu olarak psikolojik baskılar gördükten sonra kendilerine sunulan hediye ve atıyyelerle evlerine gönderilmişlerdir. Bu süreçte yanlış bir hareketlerinin sadece kendilerinin değil, aynı zamanda eşlerinin ve çocuklarının da kanı ve namusuna mal olacağını, ${ }^{37}$ tam tersine aksilik çıkarmadıkları sürece de müreffeh bir hayat yaşayabileceklerini görmeleri, muhtemelen intikam hislerini büyük ölçüde bastırmalarına yol açmıştır.

Hz. Hasan’n çocuklarından üçünün Kerbelâdan sağ kurtuldukları tahmin edilmektedir. ${ }^{38}$ Bunlar arasında o dönemlerde yaşları daha olgun olan Hasan (el-Müsennâ) ile Zeyd ön plana çıkmaktadır. Zeyd'in bilahare kızlarından birini halife Abdülmelik b. Mervan ile evlendirdiği, oğullarından birinin de Abbâsîler döneminde Mansur'un Medine valisi olduğu ifade edilmektedir. ${ }^{39}$ Zeyd'in sonraları Muhammed b. Hanefiyye’nin oğlu Ebû Hâşim aleyhine ithamlarda bulunduğu ve siyasi faaliyetlere giriştiği gerekçesiyle onu halifeye şikâyet ettiği; ${ }^{40}$ Kerbelâ sonrasında ise kız kardeşiyle evli olan İbn Zübeyr’e tabi olduğu görülmektedir. ${ }^{41} \mathrm{Bu}$ tavırları ile onun diğer Hâşimoğullarından ayrıştı̆̆ı ve muhalefetin etrafında birleşeceği bir aday olmadığı anlaşılmaktadır.

Hasan b. Hasan ise (ö. 97/715-16), toplumun saygınlığını kazanma konusunda daha ön plana çıkmış gibi gözükmektedir. Muhammed b. Hanefiyye’nin bir kızı ile de evlenmiş olan Hasan, İbn Zübeyre biat etmeme hususunda diğer Hâşimoğulları ile birlikte hareket etmiş ve Muhammed b. Hanefiyye ile birlikte o da hapsedilmiştir. ${ }^{42}$ Hasan b. Hasan'in ibadete ve ilme ağılık verdiği, etrafında toplanıp kendisine hürmet gösterenleri ve övenleri azarladığ1 görülmektedir. Ona göre Ali evladı zühd ve ibadet hususunda daha hassas olmalıydı. Zira

37 Yezid'in sarayında Suriyeliler savaş ganimeti olarak Hz. Ali’nin kızlarını kendilerine istemişler ve Yezid de bir müddet bu talebi karşılayacakmış gibi davranmıştır. Bir başka seferde Hasan’nn hayatta kalan küçük oğlu Amr’ (Ömer diyenler de var) kendi oğluyla güreşe teşvik etmiş ve onun intikam dolu cevabı üzerine büyüklerinin yanında tehditkâr konuşmuştur. Bk. İbn Sa'd, Tabakât, VI, 448-449; Taberî, Târîh, III, 339. Yezid’in şefkat ve acıma ile tehdit ve öfke arasında gelip giden davranışları, muhtemelen psikolojik bir gövde gösterisinden ibaretti ve büyük ölçüde de işe yaradığı anlaşılmaktadır.

Hasan’’n Hüseyin isimli bir dördüncü çocuğunun hayatta kaldığı da ifade edilir. Bk. Gülgün Uyar, Ehl-i Beyt - İslâm Tarihinde Ali-Fatıma Evlâdı, İstanbul: Gelenek Yayıncıllk, 2004, s. 562-563. Ancak Hasanî soyun Hasan ve Zeyd ile devam ettiği, diğer ikisinin neslinin kaybolduğu tahmin edilmektedir. Bk. Ebu Hasan Ali b. Hüseyin Mes'udî, Kitâbu't-Tenbîh ve'l-işrâf (trc. Ramazan Şeşen), İstanbul: Bilge Kültür Sanat, 2018, s. 212. İbn Sa'd, Tabakât, VII, 313. Güneş, "Ebû Hâşim Abdullah’in Siyasî Etkinliği", s. 284.

Güneş, İbnü'l-Hanefiyye, s. 138.

Güneş, İbnü'l-Hanefiyye, s. 137. 
Hz. Peygamber’e yakınlığın getirdiği sorumluluğun anlamı imamet değil, zühd ve takvayd.. ${ }^{43}$ Onun ilk halifelere lanet okuyanları yanından kovduğu, Iraklılardan gelen talepleri reddettiği, hatta onlarla mücadele etmek gerektiğini söylediği rivayet edilir. ${ }^{44}$ Onun bu tavrına rağmen torunları İbrahim (ö. 145/763) ve Muhammed Nefsü’z-Zekiyye (ö. 145/762) Abbâsî döneminde hilafet iddiasıyla bir isyan hareketi başlatmışlardır. Burada Muhammed b. Hanefiyye ve çocuklarının geçirdiği süreçle bazı benzerlikler kurulabilir. İlk başlarda ailenin önde gelenleri, özellikle siyasi angajmanı olan taraftarlarla aralarına belli bir mesafe koymaya çalışmışsa da sonraki jenerasyonlarda bu ilişkilere temayül edenler olmuş; hatta dağılan başkaca Şia fırkalarından transfer olan insanlar ve beraberlerinde taşıdıkları inançları etraflarına çeken cazibe merkezleri haline gelmişlerdir.

Son olarak Kerbelầda hayatta kalarak Hicaz’a geri dönen Ali el-Esgâr b. Hüseyin Zeyne’l-Abidin'i ele almak gerekir. Sonraki asırlarda etkili olan birçok Şii fırkanın imam saydığ Ali b. Hüseyin'in niçin yaşadığı dönemde daha ön planda olmadığı, Muhtâr’ın niçin onun değil de Muhammed b. Hanefiyye adına ortaya çıktığı ve Abdullah b. Zübeyr'in Hâşimî şahsiyetlerle biat konusunda girdiği çekişme ile ilgili rivayetlerde niçin onun değil de İbnü’l-Hanefiyye’nin ismiyle karşılaşıldığı, bu makalenin sorunsalı açısından üzerinde durulması gereken önemli sorulardır. Neticede o hilafet iddiasından vazgeçmiş olan Hz. Hasan’ın değil, bilakis bu yola başını koymuş olan Hz. Hüseyin'in oğludur ve Kerbelâ faciasından canlı olarak kurtulmuş az sayıdaki Ehlibeyt mensuplarından birisidir. Kerbelâyya katılmış olsa da hastalığı nedeniyle savaş meydanına çıkamamış ve öldürülmekten, bilahare Muhtâr tarafından idam edilen Ömer b. Sa'd b. Ebî Vakkâs (ö. 66/686) sayesinde kurtulmuştur. ${ }^{45}$ Kerbelâ sonrasında Şam’a götürülen diğer Ali evladı gibi o da burada hem hürmet görmüş hem de yukarıda ifade edildiği üzere muhtemelen üstü kapalı tehditlere maruz kalmıştır. Her hâlükârda onun Medine’ye döndükten sonra Emevi hilafetine karşı herhangi bir faaliyette bulunmadığı anlaşılmaktadır. Öyle ki, Emevi hanedanı Medine ahalisinden çok sayıda insanın öldürüldüğü Harre vakıasında başta Mervan’ın (ö. 65/685) eş ve çocukları olmak üzere ona emanet edilmiş; ona güven duyulmuştur. Gaddarlığı ile tanınan Müslim b. Ukbe (ö. 63/683), sadece onun ve onun himmetiyle Hâşimoğullarından birkaç kişinin ${ }^{46}$ Yezid’e biatlarını normal bir şekilde tazelemesine izin vermiş, diğer herkesten Yezid’e kul ve köle olmak üzere biat almış, bu şekilde biat etmeyenleri ise öldürtmüştür. ${ }^{47}$

Yezid'in vefatı sonrasında hilafet iddiasını aleni olarak dile getiren ve kendisine biat etmeleri için özellikle Hâşimoğullarına yönelik baskı kuran Abdullah b. Zübeyr'in Ali b. Hüseyin ile ilişkisine dair pek bir bilgi yoktur. Yine bu yıllarda Hz. Hüseyin’in intikamı adına

43 İbn Sa'd, Tabakât, VII, 314.

44 Recep Uslu, "Hasan b. Hasan b. Ali”, DIA, XVI, 324.

45 İbn Sa'd, Tabakât, VII, 210.

46 Söz konusu kişiler arasında Muhammed b. Hanefiyye’nin Medine’de kaldığı anlaşılan çocuklarından Ebû Hâşim ve Hasan’ın da olduğu rivayet edilmiştir. Bk. İbn Sa‘d, Tabakât, VII, 213. Öte yandan İbn Kuteybe (ö. 276/889) Ali’nin yanındaki kişileri oğulları olarak tarif etmektedir. Bk. İbn Kuteybe, el-İmâme, s. 293-294. 
ortaya çıkan Muhtâr'ın da Kerbelầdan sağ kurtulmuş olan "Hüseyin oğlu Ali" yerine Kerbelầya katılmamış olan Hüseyin'in kardeşi Muhammed b. Hanefiyye adına hareket ettiğini iddia etmesi de ilginçtir.

Ali b. Hüseyin'in Muhtar’a karşı tutumu oldukça mesafelidir. Oysa Hz. Hüseyin'in Kûfe'ye yönelmeden önce oradaki ortamı araştırması ve hareketi organize etmesi için oraya gönderdiği amcaoğlu Müslim b. Akîl (ö. 60/680) bir süre Muhtâr’n evinde kalmış, hatta bu sebeple Muhtâr hapse atılmıştır. Buna rağmen, Muhtâr’n Kûfe'yi ele geçirdikten sonra Ali b. Hüseyin'e 100 bin dirhem gönderdiği, onun da bundan hoşlanmadığı rivayet edilir. Elimizdeki diğer rivayetler de Ali b. Hüseyin'in Muhtâr’’ hiç sevmediğini, o öldükten sonra ona aleni bir şekilde lanet ettiğini, birinin Muhtâr’ın Ehlibeyt adına öldürüldüğünü ifade etmesi üzerine de Muhtâr’’n Allah ve Resûlü hakkında yalan söylediğini ileri sürdügünü göstermektedir. ${ }^{48}$ Onun bu tavırlarına rağmen Muhtâr, Kerbelâ faciasının baş mimarı olan Ubeydullah b. Ziyad'ın (ö. 67/686) kesilmiş başını Ali b. Hüseyin’e göndermiş ve elçiye o anın etkisini azami derecede arttıracak şekilde uygun bir zamanı kollamasını emretmiştir. ${ }^{49}$

Ali b. Hüseyin'in mizaç olarak da mütevazi olduğu ve kendilerine yöneltilen teveccühten rahatsızlık duyduğu, insanlara yanlış yönetim ve zulüm konusunda sabırlı olmayı tavsiye ettiği anlaşılmaktadır. ${ }^{50}$ Her ne kadar kimi Şii kaynaklar onun imametin sorumluluğunun farkında olduğunu ve bir dönem imamet iddiasında bulunan Muhammed b. Hanefiyye'nin Ali b. Hüseyin ile Hacerü'l-Esved başında yaptığı görüşme sonrasında Ali’nin lehine bu iddiasından vazgeçtiğini iddia etse de, ${ }^{51}$ netice itibariyle ele aldığımız dönemde Ali b. Hüseyin’in herhangi bir muhalefet arayışına yanaşmadığı, bu tür hareketlere bilenenleri de Hasan b. Hasan gibi yanına yanaştırmamış olduğu dikkat çekmektedir. Bilakis Harre olayında da net bir şekilde görülebileceği gibi Emevi ailesinin kendilerini emanet edecek kadar güvenlerini kazandığı gözlenmektedir.

Esasında bu duruşun, Muhammed b. Hanefiyye’nin duruşundan pek bir farkı yoksa da kanaatimizce Muhammed b. Hanefiyye’yi bu dönemde özellikle bazı hususiyetleri ön plana çıkarmıştır. Her şeyden önce Kerbelâ sonrasında o Ali evladının en büyüğüdür. Her ne kadar kendisi Hz. Peygamber'in torunu değilse de bu husus, özellikle Emeviler ve Abdullah b. Zübeyr gibi Peygamberle akrabalık bağ nemde çok da önem taşımamıştır. Bu kısımdan da anlaşılacağ şimoğulları içinde potansiyel olarak öne çıkan adaylar arasında sosyal ama aynı zamanda dirayetli duruşu ile temayüz eden iki kişiden biri Muhammed b. Hanefiyye'dir, (diğeri ise

İbn Sa'd, Tabakât, VII, 211. Rivayete göre, Ali bu parayı iade etmek istemiş ancak bundan çekinmiştir. Muhtâr öldürüldükten sonra Emevi halifesi Abdülmelik b. Mervan’a yazdığı mektupta bu hususu da açmış ve kendisine gönderilen bu meblağı halifeye devredebileceğini dile getirmiştir. Bk. İbn Sa‘d, Tabakât, VII, 211.

Rivayete göre kesik başı taşıyan elçi, Ali b. Hüseyin’in evinin kapılarının yemek için açıldığı ve insanların onun evinde toplandığı bir anı kollamıștır. Bk. Ebü’l-Abbâs Ahmed b. Ebî Ya‘kūb İshâk b. Ca‘fer b. Vehb b. Vâzıh (Ya‘kūbî), Tarîhu'l-Ya'kūbî, I-II, Beyrut: Müessesetû'l-'Ilmî li'l-Matbuât, 1993, II, 176.

İbn Sa'd, Tabakât, VII, 211-212, 214, 217-219.

Güneş, İbnül-Hanefiyye, s. 139. 
Abdullah b. Abbâs'tır). Aşağıda vereceğimiz gelişmelerin belirlediği ortam, Muhammed $b$. Hanefiyye’nin Hâş̧imoğullarının lideri olarak temayüz etmesinde ve etrafında belli bir taraftar kitlesinin oluşmasında etkili olmuştur.

\section{H. 63-68 Yılları: Muhammed B. Hanefiyye İsminin Ön Plana Çıktığı Yıllar}

Muhammed b. Hanefiyye’nin etrafındaki çoğunluğun güçlü ısrarlarına ve baskılarına rağmen sakin, ama inatçı duruşuna dair ilk ciddi örnekle Harre olayı sırasında karşılaşıyoruz. Bu olaydan kısa bir süre önce Medine’nin önde gelen şahsiyetlerinden oluşan bir ekibin, Medine’nin sık değişen valileri başta olmak üzere, muhtelif sıkıntılarını görüşmek için Şam’a halife Yezid'i ziyarete gittiklerini görüyoruz. Dönüşte heyet Yezid’i Medinelilere kötülemiş ve onun Müslüman bir yöneticiye uygun davranışlar içinde olmadığını ileri sürmüşlerdir. ${ }^{52} \mathrm{Bu}$ iddialar, muhtemelen tek başına Medinelileri bir kalkışmaya sevk edecek derecede etkili olmasa da, hem Kerbelâ faciasının etkisi ${ }^{53}$ hem Abdullah b. Zübeyr'in telkinleri ${ }^{54}$ hem de iktisadî sebeplerle ${ }^{55}$ birleşince Medinelilerin şehirdeki Emevileri kovarak Yezid’e karşı bir isyan başlatmalarına sebep teşkil etmiştir. ${ }^{56}$

Söz konusu olay, Muhammed b. Hanefiyye’nin duruşunu ortaya koyması açısından önemlidir. Direnişin lideri Abdullah b. Mu'tî (ö. 74/693) ve beraberindekilerle Muhammed b. Hanefiyye arasında geçen konuşmalar kayda değerdir. İbnü'l-Hanefiyye, onların Yezid’e isnad ettikleri davranışları Yezid'in yanında kaldığı sürece görmediğini, bilakis gördüğü kadarıyla onun dine bağlı biri olduğunu nakleder. Karşı tarafın Yezid'in İbnü'l-Hanefiyye’nin yanındayken riya yaptığını söylemeleri üzerine, halifenin bunu kendisinin yanında yapmasının çok anlamlı olmadığını, böyle bir göz boyamayı onlara karşı yapmasının daha anlamlı olacağını ima eder. ${ }^{57}$

İbnü'l-Hanefiyye’nin Yezid'i bu şekilde savunmuş olması yadırganmış ve onun Radva Dağı’na ebedi bir sürgüne gönderilmesinde bu tavrının etkili olduğu ileri sürülmüş olsa $\mathrm{da}^{58}$ bu tavır onun gelecekte karşılaşacağı tüm baskılar karşısındaki duruşu ile uyumludur. Ona göre, biat önemli bir hukukî bağdır ve çok ciddi bir gerekçe olmadan biattan geri

52 Taberî, Târîh, III, 350 .

53 Bu tartışmaya açık bir husustur. Zira Hâşimoğullarından hiçbirinin bu direnişe katılmamış olması, sebebin Kerbelâ olmadığını akla getiriyor. Yine de Kerbelâ travmasının insanları iktidara hınç bileyen bir noktaya taşımış olması muhtemeldir.

54 Medinelilerin kalkışması ile Abdullah b. Zübeyr'in çıkışı doğrudan ilişkili değildir. Nitekim İbn Zübeyr'den biat hususunda bir çağrı gelmesine rağmen Medineliler bunu kabul etmemiş görünüyor. Yine de Abdullah b. Zübeyr'in bu isyanı desteklediği tahmin edilmektedir. Bk. Mustafa Sabri Küçükaşcı, "Harre Savaş”, DİA, XVI, 245.

55 Sebeplerle ilgili detaylı bir çalışma için bk. Kılıç, "Harre Vakıasının Sebepleri Hakkında Bazı Mülahazalar”, s. $317-$ 324.

Taberî, Târîh, III, 354.

57 Detaylar ve değerlendirmeler için bk. Kılıç, "Harre Vakıasının Sebepleri Hakkında Bazı Mülahazalar”, s. 320 ve dp. 13; Güneş, İbnü'l-Hanefiyye, s. 154-160.

Güneş, İbnü'l-Hanefiyye, s. 160. 
dönülmemelidir. Bu sebeple İslam âleminin umumunun arkasında durduğu insana biat edilmelidir. Müslümanların arasında fitne çıkarmak büyük bir suçtur ve Müslümanların birbiriyle mümkün olduğunca savaşmaması lazımdır. Bu yüzden isyan etmek yerine sabretmek, ama bu duruşu da sonuna kadar savunmak gerekir. ${ }^{59} \mathrm{Bu}$ düşünceleriyle onun pasif direniş diyebileceğimiz bir duruş sergilediğini görüyoruz. Nitekim İbn Zübeyre karşı ortaya koyduğu tavır da bunun aynısıdır.

İsyanı bastırmak için gönderilen Müslim’in ordusu Medine'ye vardığında İbnü’l-Hanefiyye ailesiyle birlikte Mekke'ye geçmek istemiş, şehri kuşatan ordu ile karşılaştığında yaşanan arbede sırasında oğullarından biri öldürülmüş; bunun üzerine büyük oğlu Ebû Hâşim de kardeşinin katilini öldürmüştür. Neticede Muhammed b. Hanefiyye Mekke’ye gidebilmişse de çocuklarından en azından Ebû Hâş̧im Medine’de kalmış ve diğer Hâşimoğulları gibi evine kapanmıştır. Medine’de, diğer Hâşimoğulları gibi ona, ailesine ve mallarına dokunulmamıştır. ${ }^{60}$

Mekke’ye geçen Muhammed b. Hanefiyye, burada Abdullah b. Zübeyre biat etmemiş; Yezid'in ölümüyle yarım kalan Mekke muhasarasında da destek vermemiştir. Diğer yandan bu sırada Kerbelâ öncesi Hz. Hüseyin'in Kûfe'ye gönderdiği amcaoğlu Müslim b. Akîl'i evinde sakladığı için Kûfe'den sürülen Muhtâr da Mekke'de olup İbn Zübeyr'in yanında savaşmaktadır. İbn Zübeyr başlangıçta Muhtârın yanında olmasını istemese de muhtemelen yaklaşan Emevi ordusu sebebiyle kendisine katılmasına itiraz etmemiştir. Muhtâr ile Muhammed b. Hanefiyye'nin ilk karşılaşmasının burada olması pek muhtemeldir. Daha sonraları İbn Zübeyr'den fazla yüz bulamayacak olan Muhtâr'ın Muhammed b. Hanefiyye adına bir iddia ile ortaya çıkmasında buradaki ünsiyetin etkili olması mümkün gözükmektedir. ${ }^{61}$ Nitekim İbn Sa’d, Abdullah b. Zübeyr ile Muhtâr arasında geçen olaylarla ilgili rivayetlerde Muhtâr'ın Mekke’de İbn Zübeyr'in yanında savaştı̆̆ dönemde Muhammed b. Hanefiyye’ye de uğradığını nakletmektedir. ${ }^{62}$ Her hâlükârda burada görüştükleri anlaşılmaktadır. İbn Sa'd'n Tabakât'ında geçen bir rivayete göre Muhtâr ile İbnü’l-Hanefiyye’nin ilişkisi değişkenlik arz etmektedir. Bu rivayete göre İbn Zübeyr’in takdir ettiği Muhtâr, Muhammed b. Hanefiyye’ye çelişkili davranmakta, İbnü’l-Hanefiyye de onun fikirlerinin çoğuna karşı çıkmaktaydı. Muhtâr, İbnü'l-Hanefiyye ve İbn Zübeyr'in bu şekilde aynı rivayet içinde anılması, bu ilişkilerin Mekke’de geçtiği izlenimini vermektedir. Aynı rivayetin devamında Muhtâr, Irak’a gitme kararını İbnüll-Hanefiyye’ye açınca ondan onay almış, ancak İbnü'l-Hanefiyye ona güvenmediği için Abdullah b. Kâmil el-Hemdanînin (ö. 67/686) de onunla gitmesini istemişve bu kişiye de Muhtâra güvenmemesi gerektiğini salık vermiştir. Ardından İbn Zübeyr’den de izin alan Muhtâr bu kişiyle Irak’a gitmiştir. ${ }^{63}$

59 Onun bu şekilde özetlenebilecek görüşlerini ortaya koyan rivayetler için bk. İbn Sa‘d, Tabakât, VII, 97-99.

60 Güneş, "Ebû Hâş̧im Abdullah’in Siyasî Etkinliği", s. 264-265.

61 Belâzûrî, Ensâbü'l-eşrâf, VI, 378-380.

62 İbn Sad, Tabakât, VI, 492.

63 İbn Sacd, Tabakât, VII, 99. 
Taberi’nin Tarih'inde Muhtâr ile ilgili olayların anlatıldığ kısımlarda Abdullah b. Kâmil ismiyle sık sık karşılaşıyoruz. Yemenli Hemdanî ve Şakirî olarak tanınan bu zat, ${ }^{64}$ Muhtâr’n yakın dava arkadaşlarından biri olarak karşımıza çıkmaktadır. Kûfe’ye ilk gittiğinde hapse atılan Muhtâr'ın, bu arada mağlup edilen ve dağıtılan Tevvâbûn hareketinden arta kalanlara yazdığı mektubun ulaştığı Süleyman b. Surâd (ö. 65/685) taraftarları arasında Abdullah b. Kâmil de yer almaktadır. Abdullah, Muhtâra İbrahim b. el-Eşter’i (ö. 72/691) tavsiye eden Kûfeli Şiảnın ileri gelenlerinden olup Muhtâr'ı̀n İbn Eşter’e götürdüğü heyettedir ve Muhtâr'ın Muhammed b. Hanefiyye'den kendisine geldiğini iddia ettiği mektubun gerçekten ondan olduğuna şahitlik etmiştir. ${ }^{65}$ Muhtâr’n hatadan masum olduğunu iddia edecek kadar ona bağlıdır ve o vakitler İbn Zübeyr' in Kûfe valisi olan Abdullah b. Mu'tînnin nerede saklandığını Muhtâra iletecek kadar da geniş bir çevresi vardır. Onun bu bağlılı̆̆ karşısında Muhtâr da Abdullah b. Kâmil’i şurta kurumunun başına getirmiştir. Abdullah, bu konumu sayesinde Hüseyin'in katillerinden intikam alınmasında oldukça faal bir rol oynamıştır. En nihayetinde Muśab b. Zübeyr' in ordusu ile yapılan savaşta da öldürülmüştür. ${ }^{66}$ Muhtâra güvenmediği ifade edilen Muhammed b. Hanefiyye’nin yanına verdiği bir kişinin Muhtâr’ın bu kadar sadık bir takipçisi olması ilginç bir durum olarak karşımıza çıkmaktadır. Bir ihtimal olarak, rivayetlerin tutarsız olduğu ve bir isim karışıklı̆̆ının olduğu düşünülebilirse de, bu şahsın zaman içinde Muhtâra bağlanmış olması daha muhtemel gözükmektedir. Zira bu şahsın ilk başlarda Tevvâbûn hareketine destek verdiği anlaşılmaktadır. Son olarak bağlamı genişletebilir ve bu kişinin zaten Ehlibeyte yakın duran bir Kûfeli olduğunu, esasında İbnü’l-Hanefiyye’nin adamı olmadığını, o sıralar Hicaz'da bulunduğunu ve Kûfedeki günlerinden tanıdığ 1 Muhtâr'la ${ }^{67}$ karşılaştığ 1 için onunla birlikte yola çıma kararı aldığını ve İbnü'l-Hanefiyye'nin onun şahsında Kûfe'ye genel bir uyarıda bulunduğunu da düşünebiliriz. Bu rivayetleri bir arada değerlendirdiğimizde ya Muhammed b. Hanefiyye'nin Muhtâra karşı olumsuz tavrına rağmen Abdullah b. Kâmil'in Muhtâra inandığını veya Muhammed b. Hanefiyye’nin Muhtâra kendi namına bir davet yapması için izin verdiğini düşündüğ̈nü kabul etmek durumundayız.

64 Taberî, Târîh, III, 485.

65 Söz konusu mektubun hikâyesini anlatan ve eş-Şa'bî olarak tanınan meşhur fakih Amir b. Şerâhil de İbn Eşter’e giden heyetin içindedir. Rivayetinde mektubun sıhhati yönünde şüphe uyandıracak değerlendirmelerde bulunsa da neticede beraber gittiği insanların hatırı sayılır kişilerden oluşmaları ve doğruyu söylediklerine dair yemin etmeleri sebebiyle o da bu konuda şüphelerini ifade edecek bir söz söylemez. Bk. Taberî, Târîh, III, 437-439. O, kendisini ve babasını Muhtâr'a icabet edenlerin ilkleri arasında saysa da Muhtâr’’n özellikle kehanetlerine karşı mesafeli duruşunu sonuna kadar sürdürmüştür. Bk. Taberî, Târîh, III, 482. eş-Şa'bî, çok sayıda sahâbeden hadis ve rivayet nakletmiş ve Medine'de de vakit geçirmiş olmasına rağmen Muhammed b. Hanefiyye'den rivayetinin olmaması ilginçtir. Öyle anlaşıllyor ki eş-Şa‘bî, zaman içinde Muhtâr hareketinden ayrılmış, Şia’dan kopmuş, hatta Mürcie aleyhine de konuşmuş, ama buna rağmen Hâşimoğullarının salihlerini sevme konusunda tavsiyede bulunmuştu. Bk. İbn Sa‘d, Tabakât, VIII, 367. Muhtar’dan veya hareketinin neticesinden kaçıp Medine’ye geldiği doğru olsa bile Muhammed b. Hanefiyye ile çok fazla bir irtibat kurmadı̆̆ı anlaşılmaktadır.

67 Hatırlanacağı gibi Muhtâr, Hüseyin b. Ali’nin kuzeni Müslim b. Âkîl'i evinde saklamış ve bu yüzden hapse atılmıştı. Bk. Belâzûrî, Ensâbü'l-eşrâf, VI, 376. Nitekim Hüseyin’e ve ardından Süleyman b. Surâd’a destek verenlerden önemli bir kısmı Muhtâr’a destek vermiştir. Aralarından Rifâa b. Şeddâd gibi bazıları ise önceleri Muhtâr’ın davetine uymakla birlikte kısa süre içinde ona tavır almışlardı. Bk. Taberî, Târîh, III, 458. 
Öte yandan Muhtâr’’n İbn Zübeyr ile ilişkileri, Kûfe’ye gidişi ve sonraki gelişmeler ile ilgili oldukça detaylı bilgiler veren Taberînin Muhtâr ile İbnü'l-Hanefiyye’nin yüz yüze görüştüklerine dair net bir bilgiden bahsetmemesi dikkate değerdir. Muhtâr, insanlara kendini mehdi Muhammed b. Hanefiyye’nin elçisi olarak tanıtmaktadır, ${ }^{68}$ ama ikilinin karşılıklı görüşmelerine dair Taberînin bir atfı bulunmamaktadır. Belâzûrînin (ö. 279/892-3) Ensâb’inda Muhtâr'ın İbnü'l-Hanefiyye'ye intikam niyetini açıç̧a ifade ettiği ve bu konuda müspet veya menfi bir cevap alamayan Muhtâr'n bunu onay olarak kabul ettiği rivayet edilmektedir. Aynı yerde geçen bir başka rivayette ise, İbnü'l-Hanefiyye'nin intikam alınmasından hoşlanacağı, ama sırf bu yüzden kan dökülmesine onay veremeyeceği ve intikamı Allah’tan beklediği ifade edilmektedir. ${ }^{69}$ İbn Sa'd'n Tabakât'ında geçen rivayete göre ise Muhtâr esasında Kûfe’ye İbn Zübeyr'in izni ve güvenini sağlayarak gitmiştir. Kerbelầda Emevi ordusunun üst yönetiminden yakaladıklarının başlarını almış ve İbn Zübeyr’e göndermiştir. Baştan beri niyeti bozuksa da bu niyetini Mus’ab b. Zübeyr'in Basra’ya vali olarak gelişiyle açığa vurmuş ve ancak bundan sonra Muhammed b. Hanefiyye namına davete başlamıştır. ${ }^{70}$

Neticede, başarısız Tevvâbûn hareketi sonrasında Muhtâr'ı, Kûfe'de mehdi olarak ilan ettiği Muhammed $b$. Hanefiyye adına Ehlibeyt'in intikamını alacağı vaadiyle davette bulunurken görüyoruz. Muhammed b. Hanefiyye’nin bu davete yönelik tutumu çok tartışılmıştır. Biz rivayetleri toplu olarak değerlendirdiğimizde, İbnü'l-Hanefiyye’nin muhtemelen Muhtâr'in ilk çıkış sebebine (Ehlibeyt' in intikamını almak) şartlı onay verdiğini, ancak onun bu işle ilgisi olmayan taraflarla savaşa girmesine, şahsını mehdi, kendisini de vezir ilan ederek adına bir bağımsızlık hareketi başlatmasına, şehir/devlet yönetmeye ve vergi toplamaya kalkışmasına taraftar olmadığını düşünüyoruz. ${ }^{71}$ İbnü'l-Hanefiyye, Kûfe'de Ehlibeyt'in intikamı yönünde bir hareketlilik olduğunu (Süleyman b. Surâd ve Tevvâbûn) muhtemelen Hicaza gelip giden ve Ehlibeyt'e haber taşıyan insanlardan duymuştur. Muhtâr'ın da onay talebini onlara katılma arzusu olarak değerlendirmiş olabilir. Bu yorum, hem yukarıda ismi geçen Abdullah b. Kâmil'in tutumunu hem de İbnü'l-Hanefiyye ile Muhtâr'ın ilişkisini daha tutarlı bir şekilde açlklayabilmektedir.

Kaynaklarda geçen bir olay bu görüşümüzü desteklemektedir. Buna göre, Kûfeli bir grup insan Muhtârın Muhammed b. Hanefiyye’nin elçisi olduğuna dair iddiası konusunda şüpheye düşmüşler ve Medine’ye gidip konuyu İbnü'l-Hanefiyye'den teyit etmek istemişlerdir. Ali evladı destekçisi olarak bilinen Yemen’in Hemdan kabilesine mensup Abdurrahman b. Şureyh, çoğu Hemdanlı ve Ali evladına verdikleri destekle bilinen insanlardan oluşan bir grup (toplandıkları evin sahibi Tevvâbûn hareketi sırasında yaralanmış biri) içinde, Muhtâra destek vermekle

Belâzûrî, Ensâbü'l-eşrâf, VI, 380.

İbn Sa‘d, Tabakât, VI, 491-494.

Örneğin, kendisine mehdi diye hitap edildiğinde İbnü'l-Hanefiyye’nin kızdığı ve kendisinin ancak hayra ve doğruluğa rehberlik ettiğini söylediği anlaşılmaktadır. O, adıyla veya künyesiyle çağrılmayı uygun buluyordu. Bk. İbn Sa'd, Tabakât, VII, 96. 
birlikte onun iddia ettiği gibi gerçekten de Muhammed b. Hanefiyye’den onay alıp almadığını sorgulamıştır. Bu belki de yadırgadıkları bazı hususlara şahit oldukları içindir, zira Abdurrahman’ın "Dünya namına hiçbir şey bizim için dinimizin selametinden daha tercih edilebilir olmamalıdır" sözleri, bu yönde bir endişeye işaret ediyor gibi durmaktadır. ${ }^{72}$ Neticede bu kişiler, Muhammed b. Hanefiyye’nin yanına gitmiş ve Muhtâr'ın onun namına ortaya çıkıp Hz. Hüseyin'in kanını talep ettiğini söyleyerek bu durumun aslını ona danışmak için geldiklerini ifade etmişlerdir. Belâzûrînin kaydettiği rivayette heyetin sorusu bundan ibaret gözükürken, Taberî Muhtâr'ın "Allah'ın kitabı ve Peygamberin sünnetine davet, Ehlibeyt' in kanının intikamı ve zayıfların korunması için” davette bulunduğunu nakletmiştir. Heyet, Muhtâra bu hedefler için kendisine biat ettiklerini, ama işin aslını öğrenip Muhammed b. Hanefiyye’nin talimatı doğrultusunda hareket edeceklerini söylemiştir. Muhammed b. Hanefiyye’nin cevabı tarihçiler için oldukça tartışmalı bir alan açmıştır. İbnü’l-Hanefiyye, ailesi ve ağabeyi ile ilgili birkaç cümle sarf ettikten sonra Muhtâr'ın daveti (Ehlibeyt'in intikamı) ile ilgili olarak "Allah bizlere kullarından herhangi biri ile yardım edebilir" şeklinde bir ifade kullanmış, oradaki heyet de "İbnü'l-Hanefiyye eğer Muhtâra uyulmasını istemeseydi aleni bir şekilde 'Onu takip etmeyin', gibi bir ifade kullanırdı" mülahazasıyla bunu bir onay olarak telakki etmiştir. Heyetin böyle müspet bir cevapla dönmüş olması Muhtâr’’ büyük bir sevince boğmuştur. ${ }^{73}$

Muhammed b. Hanefiyye’nin bu cevabı, onun Muhtâr'ın hareketine olan desteği konusundaki gizemi pekiştirmiştir. Biz, özellikle sırf bunu öğrenmek için Kûfe'den Medine’ye olan uzun yolu göze alan böyle iddialı ve hevesli bir heyetin tartışmaya açık bir cevaba rıza göstererek döndükleri ihtimalini yadırgıyoruz. Kanaatimizce İbnü'l-Hanefiyye'nin cevabı oradaki hazirûn için oldukça netti. Söz konusu cevap, bizim yukarıda ifade ettiğimiz gibi, İbnü’l-Hanefiyye’nin Muhtâra sadece intikam konusunda onay verdiği yönündeki tezimizle uyumlu gözükmektedir. Nitekim heyetin soruları da Muhtâra olan biatın büyük ölçüde bu çerçevede herhangi bir idari hedefi yansitmaksızın salt Allah ve Peygamber yoluna davet ve Ehlibeyt' in intikamı şartlarına biat bağlamında sorulmuştur. Sadece Taberî̀de geçen "zayıfların korunması" ifadesi farklı bir şekilde anlaşılabilir. Ayrıca yine Taberî̀de geçen bir rivayete göre, Kûfe’ye dönen heyetin başındaki Abdurrahman b. Şureyh taraftarlara (şia) bir konuşma yapmış ve İbnü'l-Hanefiyye’nin (ona Mehdi diyor) kendilerinden Muhtâr'a yardımcı olmalarını ve davetine icabet etmelerini istediğini duyurmuştur. ${ }^{74}$ Rivayette geçtiği şekliyle İbnü’l-Hanefiyye’nin sözlerindeki muğlaklık ile bu sözlerdeki kesinlik arasındaki farkı ve tutarsızlığ 1 açıklamak başka türlü kolay gözükmemektedir. Abdurrahman b. Şureyh konuşmasında İbnü’l-Hanefiyye’nin duruşunu abartmış olabilir, ama neticede Muhtâr'ın konumunu sorgulayan ve İbnü'l-Hanefiyye'den görüş almak için heyeti yola çıkmaya tetikleyen de bu kişidir. İbnü'l-Hanefiyye’nin mesajı (ki rivayette geçenlerden fazlasını da söylemiş olabilir) belli ki Tevvâbûn ile başlayan Ehlibeyt’in intikamı bağlamında doğru algılanmıştır.

72 Taberî, Târîh, III, 436.

73 Taberî, Târîh, III, 436-437; Belâzûrî, Ensâbü’l-eşrâf, VI, 384-385.

74 Taberî, Târîh, III, 437. 
Yine bir başka rivayete göre, Ehlibeyt'in intikamı için yola çıkmış olan Muhtâr’ın meclisinde Ömer b. Sa'd b. Ebî Vakkâs gibi Kerbelânın fâillerinden birini barındırması, Muhammed b. Hanefiyye'nin eleştirilerine sebep olmuştur. ${ }^{75} \mathrm{Bu}$ rivayet de intikam bağlamında bir ilişkinin varlığını teyit etmektedir. Nihayet bir başka rivayete göre, Kûfe'deki Şia, Muhtârın en azından başlangıçta sadece İbnü'l-Hanefiyye namına davette bulunup Ehlibeyt'in intikamını almak için harekete geçtiğini sanmıştır. ${ }^{76}$

Diğer yandan Muhammed b. Hanefiyye’nin Muhtâra hiçbir şekilde destek vermediğine delil teşkil ediyormuş gibi gözüken rivayetleri de aynı bağlam içinde değerlendirebiliriz. Mesela, Muhtâr’a karşı çıkan Kûfe eşrafı, onu eleştirirken Muhtâr’’n aslında Muhammed b. Hanefiyye tarafından gönderilmediğini iddia etmektedirler. Buna karşılık Muhtârı̉n da arzu ettikleri takdirde iki tarafın da İbnüll-Hanefiyye’ye heyet gönderebileceğini söylediği anlaşılıyor. ${ }^{77}$ Burada muhtemelen Muhtâr'ın hedefinin sadece intikam olmadığının belirginleşmesi sebebiyle eşraf tepkisini ortaya koymuş ve Muhtâr’n idareyi ele alma konusunda İbnü'l-Hanefiyye’den yetki almadığının da altını çizmiştir. Nitekim Muhtâr’’n İbrahim b. el-Eşter'i kendi tarafına çekmek için ona İbnü’l-Hanefiyye'den geldiğini iddia ettiği bir mektup sunması, ondan mehdi diye bahsetmesi, işi büyütüp sadece Kûfe’nin değil tüm Irak, Azerbaycan ve Ermenistan’ın kontrolünü ele geçirmesi, uç fikirlere sahip kesimlere göz yumması, kehanetlerde bulunarak kendisini gaipten haber alan biri gibi sunması, öyle anlaşılıyor ki, Muhammed b. Hanefiyye’nin kulağına gidince onun canını sıkmıştır. Nihayetinde Kûfe'de aşırılıkları ile tanınan bir kısım taraftarın varlığından bahsedilmesi üzerine, Kûfe'dekilere mektup yazmış ve doğru yoldan ayrılmamalarını tembihlemiştir. ${ }^{78}$

Bu durum, özellikle Müslüman kanı dökülmeye başladığında onu fazlasıyla rahatsız etmiştir. Mesela, bazı birliklerinin İbn Zübeyr tarafından hezimete uğratılması üzerine İbnü'l-Hanefiyye'ye mektup gönderen Muhtâr, Medine’ye bir ordu sevk ettiğini, ama bu ordunun İbn Zübeyr’in ordusu tarafından kandırıldığını ve yok edildiğini, eğer İbnü’l-Hanefiyye isterse ikinci bir ordu daha yollayabileceğini yazmıştır. İbnü'l-Hanefiyye ise arzusunun savaş olması durumunda kendisinin de bir ordu toplayabileceğini, ama bundan uzak durup sabretmeyi tercih ettiğini bildirmiştir. Ayrıca gelen elçiyle Muhtâra Allah’tan korkması ve artık kan dökmeyi bırakması yönünde bir mesaj göndermiştir. ${ }^{79}$

Taberî, Târîh, III, 465; Belâzûrî, Ensâbü’l-eşrâf, VI, 405-406.

Taberî, Târîh, III, 470. Söz konusu rivayetin râvisi olan Musa b. Amir, Muhtâr'ın ordusunda savaşan genç biri olup bu döneme ait birçok rivayeti aktarmıştır. Bk. Taberî, Târîh, III, 453-454.

Taberî, Târîh, III, 455-456.

Taberî, Târîh, III, 489. Bu haberi ona iletenlerden biri onu kurtarmaya gelen ordunun kumandanı ve İbn Sa'd'a göre aşırı Şii olan (bk. İbn Sa‘d, Tabakât, VIII, 347) Ebû Abdullah el-Cedelî, öbürü ise İbnü’l-Hanefiyye’nin Muhtâr’ı sadece konuşup intikam almadığı için eleştirdiğini Muhtâr’a ileten (bk. Taberî, Târîh, III, 465) ve İbnü'l-Hanefiyye'nin sapkınlıklardan uzak durulması gerektiğini tavsiye eden mektubunu da Kûfelilere taşıyan Yezid b. Şerâhil'dir. Ensarî olarak bilinen bu ikincisinin İbnü'l-Hanefiyye ile Kûfe arasındaki irtibatı sağladığı anlaşılmaktadır.

Taberî, Târîh, III, 472; Belâzûrî, Ensâbü'l-eşrâf, VI, 420-421. 
İbnü'l-Hanefiyye’nin her hâlükârda zaman içerisinde Muhtâr ile arasına mesafe koyduğu anlaşılmaktadır. Nitekim, Ensâbü̉l-eşrâfda geçen bir rivayete göre, bir müddet Muhtâr hareketine babasıyla birlikte katılmış olan meşhur fakih eş-Şa bî̀ye (ö. 104/722) Muhtâr’ın hareketinin İbnüll-Hanefiyye’nin emir ve onayı ile mi olduğu yönünde bir sual sorulmuş, o da hareketin başlangıçta böyle bir onay ile başladığını, ancak Muhtâr'ın İbnü’l-Hanefiyye’nin talep ve şartlarına uymadığını söylemiştir. ${ }^{80}$

Diğer yandan Muhtâr’ın bu ses getiren yükselişi, Hicaz'da hilafetini ilan eden Abdullah b. Zübeyr'i de oldukça rahatsız etmiş ve muhtemelen bu sebeple başta Muhammed b. Hanefiyye olmak üzere Hâş̧imoğulları üzerindeki baskısını arttırmıştır. Bu nedenle, Muhammed b. Hanefiyye daha önce yazdığı ret mektubuna rağmen Muhtâr’’n ordusuna muhtaç kalmıştır. İbn Zübeyr, tüm ümmetin ittifak ettiği biri olmadığ 1 gerekçesi ile kendisine biat etmeyen Muhammed b. Hanefiyye'yi Zemzem kuyusuna hapsettirmiş ve onu yakmakla tehdit etmiştir. Onunla birlikte ailesi ve akrabaları da hapsedilmiştir. Ancak bu rivayette onunla birlikte hapsedilenler arasında Kûfe'nin ileri gelenlerinden 17 kişinin olduğundan da bahsedilir ve bunlar aracıllğıyla Muhtâr’a haber gönderilmiştir. ${ }^{81} \mathrm{Bu}$ önemli detay, onun Kûfe ve dolayısıyla Muhtâr ile sıkıntılı olan irtibatının devam ettiğinin ve etrafında küçük de olsa bir taraftar kitlesinin oluştuğunun emaresi sayılabilir. Muhtâr, Mekke’ye farklı kişilerin komutasında parça parça birlikler göndermiş ve etraftan toplanan kuvvetlerle 4 bini bulduğu ifade edilen bu güç sayesinde ${ }^{82}$ Hâşimoğulları kurtarılmıştır. Muhammed b. Hanefiyye’nin çatışma çıkmaması yönündeki telkinlerinin de etkisiyle bu iş kan dökülmeden gerçekleştirilmiş; ardından da Muhtâr’’n gönderdiği para dağıtılmıştır. ${ }^{83}$

Muhammed b. Hanefiyye’nin İbn Zübeyr'in tüm baskı ve tehditlerine rağmen ümmetin üzerinde ittifak ettiği tek bir halife adayı olmadığı gerekçesiyle ona biat etmemesi ve

80 Belâzûrî, Ensâbü'l-eşrâf, VI, 380.

81 Belâzûrî bu kişilerin isimlerini de verir. Bunlar İbnü’l-Hanefiyye’nin Harre olayı sırasında Mekke’ye gittiğini öğrenmiş ve onun yanına gelmişler ve İbn Zübeyr’in biat konusundaki sıkıştırmalarına karşı İbnü'l-Hanefiyye’nin görüşü doğrultusunda tek bir aday kalana dek biat etmek istemediklerini ifade etmişlerdir. Sonradan onlara katılan 3 gençle sayıları 20'yi bulan bu ekipten seçilen bazı kişiler Kûfe'ye durumu bildirmek için gizlice Mekke'den ayrılmışlardır. Bunlardan Ebü'l-Mu’temir, Yunus b. İmrân (Taberî ve Belâzûrî bu kişinin ismi konusunda uzlaşamasa da muhtemelen aynı kişiden bahsetmektedirler) ve Hanî̉ b. Kays, bilahare Muhtâr tarafından Ebû Abdullah elCedelî̀nin kumandasında gönderilen ordunun birliklerini kumanda etmişler, Muhammed b. Neşr (Taberîde Muhammed b. Kays deniyor) ile Tufeyl de (son vefat eden sahâbe Ebu't-Tufeyl'in (ö. 100/718-19) oğludur. Babası da İbnü'l-Hanefiyye'nin etrafında toplananlar arasındadır) ordunun geldiğini İbnü'l-Hanefiyye’ye bildirmek için geri gönderilmişlerdi (Bk. Taberî, Târîh, III, 473; Belâzûrî, Ensâbü'l-eşrâf, III, 472-476). Öte yandan bu Kûfeli ekip içinde gözüken Abdullah b. Hanînin de bilahare Muhtâr ile birlikte öldürüldüğü ifade edilmektedir (Bk. Belâzûrî, Ensâbü'l-eşrâf, III, 472). Yine bu ekipten Hucr b. Adînnin kardeşinin oğlu olan Muaz b. Hânî Hüseyin b. Ali’nin kesik başını Kûfe'ye getiren kişi olan Havâli b. Yezid’i bulmak için Muhtâr tarafından gönderilmişti (Bk. Taberî, Târîh, III, 464). Bu topluluktan Abdullah b. Varkẩnın da İbn Eşter ile birlikte Ubeydullah b. Ziyad’a karşı savaştığına şahit oluyoruz (Bk. Taberî, Târîh, III, 480).

82 Taberî̀de geçen rivayete göre Muhtâr’’n 5 ayrı komutanın emrinde gönderdiği birliklerdeki adamların toplamı 750 kişidir (Bk. Taberî, Târîh, III, 473). Bu durumda o vakte kadar pasif bir şekilde bekleyen yerli halk, Umre için gelenler, Ehlibeyte muhabbeti olanlar ve aile fertlerinin etrafındakiler ve talebelerinin de bu aşamada kurtarma operasyonuna dahil olduğu ve tabir caizse bir gövde gösterisi yaptıkları söylenebilir.

Taberî, Târîh, III, 473. 
gösterdiği pasif direnişle sembol hale gelmesi, muhtemelen İbnü'l-Hanefiyye etrafındaki hâlenin büyümesine sebep olmuştur. Özellikle de Haşebiyye olarak bilinen ve onu kurtarmaya gelen Kûfelilerin bir kısmının artık ölünceye kadar onun yanında kaldıkları tahmin edilebilir. Özellikle de Muhtâr’ın öldürülmesini müteakip İbnü’l-Hanefiyye etrafında sürekli gelip giden ve bilahare Medine'de başlattığı derslerin müdavimi olan taraftar ve öğrencilerinin varlığ 1 belli bir insan kitlesinin artık onun etrafında sürekli kümelenmesini sağlamıştır. Nitekim Abdülmelik b. Mervan’nn daveti üzerine yapacağı Şam seyahati sırasında büyük bir kafile ile yola çıkmıştır. Bu kafile yolda daha da büyümüş, öyle ki Eyle’ye geldiklerinde meraklılarla birlikte oluşan kalabalık sebebiyle Eyle’nin valisi korkmuştur. Abdülmelik b. Mervan da onun henüz kendisine biat etmediği halde böyle bir kalabalık ve taraftar kitlesiyle beldesine girmesinden rahatsız olmuş ve haber göndererek ondan ya biat etmesini ya da geri dönmesini talep etmiştir. İbnüll-Hanefiyye de henüz İbn Zübeyr hayatta olduğundan Abdülmelik’e aynı gerekçelerle biat etmemiş ve geri dönmüştür. ${ }^{84}$

Muhammed b. Hanefiyye artık bariz bir şekilde Hâş̧imoğullarının lideri konumundadır. Bunu H. 68 yılının haccı sırasında yaşanan olaylarda net bir şekilde görüyoruz. O yıl hacılar Arafat'ta 4 sancak altında toplanmışlardır: İbn Zübeyr'e biat edenler kendi sancağı altında, Emeviler ve Abdülmelik b. Mervan’a biat edenler Şam sancağı altında, Hariciler liderleri Necdet b. Âmir'in (ö. 72/691) sancağı altında, Hâşimoğulları ve İbnü'l-Hanefiyye'nin etrafındakiler de Muhammed b. Hanefiyye’nin sancağ 1 altında hac yapmışlardır. Muhammed b. Cübeyr, kendi naklettiği rivayete göre, bu sırada bir kavga çıkmasından endişe ederek dört lideri ziyaret etmiş, onları sükunete ve itidale davet etmiştir. Bu şahıs dört topluluk içinde en sakin olanın İbnü'l-Hanefiyye sancağı altında olanlar olduğunu da kaydetmiştir. ${ }^{85}$

Görüldüğg̈ gibi Muhammed b. Hanefiyye’nin çevresinde artık kayda değer bir kitle vardır. Bunu bir teşkilat yapısı şeklinde kabul etmek mümkün gözükmese de önemli bir kısmı muhibbi diyebileceğimiz niteliktedir. İçlerinde talebeleri olduğu gibi, Kûfe'den gelenler ve mevâlî olanlar da mevcuttur. Muhtemelen önemli bir kısmını da hac için gelenler ve dolayısıyla farklı yerlerde yaşayan, farklı inançları ve geçmişleri olan insanlar teşkil etmektedir. $\mathrm{Bu}$ sebeple onun ölümünden sonra etrafında toplanan kitlenin çok farklı yönlere gitmiş olmaları doğaldır. İlimle uğraşmayı seven ve İslam’’n temel itikâdî prensiplerinden taviz vermeyen kardeşi Hasan’a nispetle daha geniş bir inanç yelpazesine sahip insanlarla dostluğu olan Ebû Hâşim’in, babasının etrafındaki kitlenin biraz daha marjinal olanlarıyla dostluğunu devam ettirmiş olması oldukça muhtemeldir. Ana kitlenin mutedil Şia veya Sünni ekollere kaydıklarını ${ }^{86}$ uç noktalarda olanların da Keysaniyye’nin temellerini oluşturduklarını tahmin edebiliriz.

Güneş, İbnü'l-Hanefiyye, s. 166-171.

Taberî, Târîh, III, 508-509.

eş-Şa'bî buna güzel bir örnektir. 
Diğer yandan Keysaniyye’ye atfedilen her inanışın da aslında bu mezhebin temel direği olduğunu düşünmemek gerekir. Örneğin, Muhammed b. Hanefiyye’nin ölmediği ve Radva Dağı’nda yaşadığı iddiası, aslında şiirsel bir güzelleme veya ağıt mahiyetinde ortaya çıkmış ve bilahare bir inanç akidesi haline gelmiş olabilir. Nitekim bunun ilk olarak, Muhammed b. Hanefiyye’nin zamanında genç bir şair olan Küseyyir'in (ö. 105/723) mısralarında telaffuz edildiğini görüyoruz. Güçlü bir şair olan ve Abdülmelik b. Mervan’a biat etmek için İbnü’l-Hanefiyye ile Şam’a giden Küseyyir, herkese uygun güzellemeler derlemesiyle tanınmaktadır. ${ }^{87}$ Onun tanıdığı ve sevdiği birinin ardından böyle bir şiir kaleme almış olması oldukça muhtemeldir. Bu, Küseyyir'in yazdıklarına itikâdî açıdan da inandığı anlamına gelmeyebilir.

\section{Sonuç}

Muhammed b. Hanefiyye, Ali b. Ebû Tâlib’in Hasan ve Hüseyin'den sonraki en büyük oğludur. Her ne kadar annesi Hz. Peygamber'in kızı olmasa da özellikle Kerbelâ sonrasında Ehlibeyt'ten çok sayıda akrabasının öldürülmüş olması sebebiyle geriye kalanlar içinde yaşça olgun ve kıdemce öndeydi. Hayatta kalan Hasan ve Hüseyin evlatları, muhtemelen hem Kerbelâ sırasında hem de bilahare Yezid'in yanında yaşadıkları tecrübeler sebebiyle, kendilerine yaklaşanları itecek ölçüde siyasetten uzak bir hayat benimsemişlerdi. Böyle bir ortamda, Muhammed b. Hanefiyye Hâşimoğullarının lideri olarak ön plana çıkmıştır. Diğer Ali evladı gibi siyaseten aktif olmadığı gözlemlense de bazı konulardaki tavizsiz ve geri adım atmayan duruşu sayesinde hem Hâşimoğulları hem de onları seven insanlar nezdinde belli bir takdir toplamıştır. Onun özellikle Müslümanlar arasında kan dökülmesine karşı takındığı tavır ile Abdullah b. Zübeyr ve mücadele ettiği Emevi halifelerinin tüm ssrar, tehdit ve baskılarına rağmen tüm ümmetin benimseyeceği ortak bir halife çıkana kadar kimseye biat etmeme yönündeki kararı, ciddi bir pasif direniş sembolü olmuştur. İbnüll-Hanefiyye, ayrıca yapılan bir biatin çok istisnai şartlar dışında bozulmaması gerektiği düşüncesiyle Yezid’e karşı ayaklanan Medinelilere de tepki göstermiştir. H. 68 yılının haccında Hâş̧imoğulları ve Ali evladı taraftarlarının onun liderliği ve sancağı altında hac yapması da onun en azından bir dönem Hâşimoğullarının lideri pozisyonunda olduğuna delil teşkil etmektedir.

Muhtâr'ın neden özellikle Muhammed b. Hanefiyye namına ortaya çıtığı ve bu iki şahsiyetin ilişkilerinin mahiyeti, İslam tarihçilerinin hâlâ tartışma konularından biridir. Bununla birlikte birbirleri ile çelişkili duran rivayetlere ve bu rivayetlerin İbnü'l-Hanefiyye’nin tavrı hususunda aktardıklarına baktığımızda en makul açıklama, Muhtâr’n gerçekten de Muhammed b. Hanefiyye'den bir şekilde onay aldığı yönündedir. Kanaatimizce bu onay, sadece ağabeyi Hüseyin ve diğer akrabalarının intikamının alınmasına yöneliktir. Nitekim Muhtâr’ın davetinin ilk şekli ve İbnü'l-Hanefiyye’ye bu konuda sorulan sorular, büyük ölçüde intikam teması üzerine inşa edilmiş gibi durmaktadır. Muhtâr’ın daha büyük siyasi

Mustafa Çuhadar, “Küseyyir”, DİA, XXVI, 576. 
emeller peşinde olduğunun ortaya çıkması, Kûfe'deki eşraf ve mevâlî dengesinin bozulması, kendi içlerinde kavgaların yaşanması ve o dönemde Sebeiyye olarak görülen din dışı söylem, inanç ve uygulamaların gözlemlenmesi, gereksiz yere Müslüman kanının dökülmesine karşı olan Muhammed b. Hanefiyye'nin bu hareket ile arasına mesafe koymasina ve bu anlamda sürekli uyarılarda bulunmasına sebep olmuştur.

Diğer yandan Muhtâr'ın hareketi sebebiyle Muhammed b. Hanefiyye'nin etrafında giderek büyüyen bir kitlenin oluştuğu görülmektedir. Nitekim Abdullah b. Zübeyr, biraz da bundan çekinerek, İbnü'l-Hanefiyye'nin kendisine biat etmesi hususunda baskılarını ve tehditlerini arttırmıştır. Hapse atıldığında ve yakılmakla tehdit edildiğinde İbnü’l-Hanefiyye’nin yanında diğer Hâşimoğullarının yanı sıra Kûfeli bazı kişilerin de bulunması dikkat çekmektedir. Her hâlükârda Muhammed b. Hanefiyye, içine düştügü kötü durumdan kurtarmak için kendisine mal ve asker gönderen Muhtar'ın bu ihsan ve ikramlarını kurtarıldıktan sonra dağıtmışsa da Kûfelilerin bir kısmının onun yanında kaldığı muhtemel gözükmektedir. İbnü'l-Hanefiyye'nin namının tüm İslam dünyasında yayılmaya başlaması da bu döneme tekabül etmektedir. Biraz da İbn Zübeyr’in baskısından uzaklaşmak için Abdülmelik b. Mervan’ın Şam davetini kabul eden İbnü'l-Hanefiyye, yola büyük bir kafile ile çıkmış, yoldan katılanlarla ve halkın ilgisiyle bu kafile Eyle’ye vardığında Emevileri korkutacak bir büyüklüğe ulaşmıştır. Abdülmelik’e biat şartıyla ilerlemesine izin verilen İbnüll-Hanefiyye, bunu İbn Zübeyr henüz hayatta olduğu için reddetmiş ve geri dönmüş olsa da etrafındaki halkanın en azından bir kısmı artık nitelik olarak kalıcı olmuştur. Sonraki yıllarda ilim ve eğitim alanındaki faaliyetlerinin de etkisiyle etrafındaki kitlenin genişlediği ve İslam âleminin farklı yerlerine yayıldığı anlaşılmaktadır. İçinde farklı nitelik ve inançlardaki insanları barındıran bu kitle, her ne kadar onun ölümünden sonra farklı yönlere dağılmış olsa da bir kısmı Ebû Hâşim’in etrafında kenetlenerek varlıklarını sürdürmüştür. 


\section{Kaynaklar}

Belâzûrî, Ebü’l-Hasen Ahmed b. Yahyâ b. Câbir b. Dâvûd. Kitâbu Cümel min ensâbi'l-eşrâf. I-XIII, Beyrut: Dâru'l-Fikr, 1996.

el-Buhârî, Muhammed b. İsmail. el-Câmiu’s-sahîh (nşr. Muhammed Züheyr b. Nâsır en-Nâsır). I-IV. Cidde: Darû't-Tevku’n-Necât. 1422/2001.

Çuhadar, Mustafa. "Küseyyir”, DİA, XXVI, 575-576.

Daftary, Farhad. "Emeviler Döneminde ve Abbasilerin İlk Dönemlerinde İran, Horasan ve Mâverâünnehir'deki Mezhebi ve Milliyetçi Hareketler” (trc. Mehmet Atalan). Kelam Araştırmaları, 2006, IV, sy. 2, s. 139-157.

Dalkıran, Sayın. "Muhammed b. el-Hanefiyye ve Adına Oluşan Fırkalar.” Dinî Araştırmalar, Mayıs-Ağustos 2004, s. 139-158.

Demir, Habip. Horasan'da Şiilik - İran'da Şiiliğin Tarihsel Kökenleri. Ankara: OTTO, 2017.

Ebû Dâvûd Süleymân b. el-Eşas b. İshâk es-Sicistânî el-Ezdî. es-Süneni Ebû Dâvûd (nşr. İzzet Ubeyd edDaâs ve Adil es-Seyyid). I-V. Beyrut: Dâru İbn Hazm. 1418/1997.

Güneş, Hüseyin. "Ebû Hâşim Abdullah’ın Siyasî Etkinliği”, İstem, 2011, IX, sy.18, s. 263-288.

------. "İslam Tarihinin İlk Mehdisi: Muhammed b. Hanefiyye." Uluslararası Mehdilik Sempozyumu Bildirileri. Sivas: Cumhuriyet Üniversitesi İlahiyat Fakültesi, 2018, s. 135-158.

------. İslam Tarihinin İlk Mehdisi İbnü’l-Hanefiyye. Mardin: Şırnak Üniversitesi Yayınları, 2018.

Hodgson, Marshall G. S. "How Did The Early Shîa Become Sectarian?? Journal of the American Oriental Society, 1955, LXXV, sy. 1, s. 1-13.

İbn Hacer el-Askalânî, Ebü’l-Fazl Şihâbüddîn Ahmed b. Alî b. Muhammed. Tehzîbü't-tehzîb. I-IV, yy., 1995.

İbn Hacer el-Askalânî, Ebü’l-Fazl Şihâbüddîn Ahmed b. Alî b. Muhammed. el-İsâbe fî temyîzis-sahâbe. Beyrut: el-Mektebetü'l-Asrîyye, 2012.

İbn Kuteybe, Ebû Muhammed Abdullah b. Müslim. el-İmâme ve's-siyâse (Hilafet ve Siyaset) (trc. Cemalettin Saylık). Ankara: Ankara Okulu, 2017.

İbn Sa‘d, Muhammed b. Sa‘d b. Menî‘ ez-Zührî. Kitâbü’t-Tabakâti’l-kebîr (thk. Ali Muhammed Amr). I-XI. Kahire: Mektebetü'l-Hancî, 2001.

Kadî, Vedad. “Keysâniyye’ye Özel Referansla İslam Kaynaklarında Gulât Teriminin Gelişimi” (trc. Yusuf Benli). Dinbilimleri Akademik Araştırma Dergisi, 2007, s. 241-276.

Kılavuz, Ahmet Saim. “Zeynelâbidîn”, DİA, XLIV, 365-366.

Kılıç, Ünal. “Harre Vakıasının Sebepleri Hakkında Bazı Mülahazalar.” Cumhuriyet Üniversitesi İlahiyat Fakültesi Dergisi, 2000, sy. 4, s. 317-324.

Küçükaşc1, Mustafa Sabri. "Harre Savaşı”, DİA, XVI, 245-247.

Kutlu, Sönmez. “İlk Mürciî Metinler ve Kitâbü’l-İrcâ.” Ankara Üniversitesi İlahiyat Fakültesi Dergisi, 1997, XXXVII, s. 317-331.

Mes'ûdî, Ebu Hasan Ali b. Hüseyin. Mürûcu'z-zeheb ve meâdini'l-cevher. I-IV. Beyrut: Daru'l-Fikr, 1997.

------. Kitâbu't-Tenbîh ve'l-işrâf (trc. Ramazan Şeşen). İstanbul: Bilge Kültür Sanat, 2018.

Müellifi Meçhul. Ahbâru'd-Devleti'l-Abbasiyye ve fîhi Ahbâri Abbas ve veledihi (thk. Abdulaziz Dûrî). Beyrut: yy., 1971.

Müslim b. el-Haccâc b. Müslim el-Kuşeyrî. Sahîh Müslim (nşr. Ebu'l-Fadl ed-Dimyâtî). Kahire: Dâr'ulBeyânu'l-Arabî. 2006.

Öz, Mustafa. "Muhammed b. Hanefiyye”, DİA, XXX, 537-539. 
Şahin, Nihal. Abbasi Devletinin Kuruluş Safhasında Abbasoğlu-Alioğlu İlişkileri (yüksek lisans tezi, 1996). Marmara Üniversitesi Sosyal Bilimler Enstitüsü.

Taberî, Ebû Ca'fer Muhammed b. Cerîr b. Yezîd. Câmi'u'l-beyân ve târîhu’l-ümem ve'l-mülûk. I-VI. Beyrut: Dâru'l-Kutub el-İlmiyye, 1971.

et-Tirmizî, Ebû Îsâ Muhammed b. Îsâ b. Sevre. el-Câmi 'u'ṣ-șahîhh (nşr. İbrahim Atveh Avd). I-V. Kahire. Muhammed Mahmud el-Halebî ve Şûrekâhu. 1395/1975.

Uslu, Recep. "Hasan b. Hasan b. Ali", DİA, XVI, 324.

Uyar, Gülgün. Ehl-i Beyt - İslâm Tarihinde Ali-Fatıma Evlâdı. İstanbul: Gelenek Yayıncılık, 2004.

Wellhausen, Julius. İslamiyetin İlk Devrinde Dini-Siyasi Muhalefet Partileri (trc. Fikret Işıltan). Ankara: Türk Tarih Kurumu, 1996.

Wikishia. "Muḥammad b. al-Ḥanafiyya”. http://en.wikishia.net/view/Muhammad_b._al-Hanafiyya (erişim tarihi:10 Aralık 2017)

Ya‘kūbî, Ebü’l-Abbâs Ahmed b. Ebî Ya‘kūb İshâk b. Ca‘fer b. Vehb b. Vâzıh. Tarîhü’l-Ya‘kūbî. I-II. Beyrut: Müessesetû'l-'Ilmî li'l-Matbuât, 1993.

Yıldız, Hakkı Dursun. “Ali b. Abdullah b. Abbas”, DİA, II, 380. 